\title{
Speciation with gene flow in marine systems
}

\author{
Gerrit Potkamp \\ Department of Taxonomy \& Systematics, Naturalis Biodiversity Center, \\ PO Box 9517, 2300 RA Leiden, The Netherlands \\ GELIFES - Groningen Institute for Evolutionary Life Sciences, Faculty of Science and \\ Engineering, Groningen University, Nijenborgh 7, 9747 AG Groningen, The Netherlands
}

\section{Charles H.J.M. Fransen}

Department of Taxonomy \& Systematics, Naturalis Biodiversity Center, PO Box 9517, 2300 RA Leiden, The Netherlands charles.fransen@naturalis.nl

\begin{abstract}
Over the last century, a large body of literature emerged on mechanisms driving speciation. Most of the research into these questions focussed on terrestrial systems, while research in marine systems lagged behind. Here, we review the population genetic mechanisms and geographic context of 33 potential cases of speciation with gene flow in the marine realm, using six criteria inferred from theoretical models of speciation. Speciation with gene flow occurs in a wide range of marine taxa. Single traits, which induce assortative mating and are subjected to disruptive selection, such as differences in host-associations in invertebrates or colour pattern in tropical fish, are potentially responsible for a decrease in gene flow and may be driving divergence in the majority of cases. However, much remains unknown, and with the current knowledge, the frequency of ecological speciation with gene flow in marine systems remains difficult to estimate. Standardized, generally applicable statistical methods, explicitly testing different hypotheses of speciation, are, going forward, required to confidently infer speciation with gene flow.
\end{abstract}

\section{Keywords}

assortative mating - disruptive selection - ecological speciation - magic trait - marine speciation speciation with gene flow 


\section{Introduction}

Since the modern synthesis of biology, speciation without gene flow has been accepted as the default mode of speciation. An extrinsic barrier splits a population and prevents gene flow between subpopulations, while genetic incompatibilities between populations accumulate through genetic drift and gradually result in reproductive isolation (Mayr, 1942, 1963). Whether reproductive isolation can arise without extrinsic barriers has long been a discussion in the field of evolutionary biology. In the absence of, for example, geographic barriers, interbreeding may impede divergence within a population, which was already recognized by Wagner (1868) in his critique on Darwin (1859). However, since the second half of the twentieth century, mathematical models of speciation with gene flow driven by disruptive selection emerged (Maynard Smith, 1966; Dickinson \& Antonovics, 1973; Rice, 1984, 1987; Johnson et al., 1996; Kawecki, 1996, 1997; Dieckmann \& Doebeli, 1999; Kondrashov \& Kondrashov, 1999; Doebeli \& Dieckmann, 2000; Gavrilets, 2004). Empirical examples of divergence in sympatry, driven by disruptive selection (i.e., divergent selection within a single, panmictic population; Rundle \& Nosil, 2005), were reported as well (Bush, 1969; Feder et al., 1988; Rice \& Salt, 1988). The paradigm of speciation in isolation as the sole mechanism of speciation slowly shifted towards a view incorporating speciation with gene flow as a plausible alternative (Bolnick \& Fitzpatrick, 2007). Currently, it is accepted that speciation can occur in the presence of gene flow (e.g., Hey, 2006; Bolnick \& Fitzpatrick, 2007; Nosil, 2008). Literature has mostly focused on the biogeographic patterns, e.g., by comparing the frequency of allopatric vs. sympatric speciation. The focus has recently shifted towards the population genetic process (Fitzpatrick et al., 2008, 2009), where we focus on here.
Most research so far has dealt with speciation in terrestrial systems, while research on evolutionary mechanisms and speciation in the marine realm has been lagging behind (Miglietta et al., 2011; Peijnenburg \& Goetze, 2013; Bowen et al., 2016). Based on a study on tropical echinoids, Mayr (1954) concluded that speciation in marine systems did not differ from speciation in terrestrial systems. However, geographic barriers are seemingly less common in marine systems compared to terrestrial systems, and many organisms have a large dispersal potential because of long pelagic larval stages (Palumbi, 1992; Hellberg, 1998; Kinlan \& Gaines, 2003; Rocha et al., 2005, 2007; Rocha \& Bowen, 2008; Miglietta et al., 2011; but see Chen \& Hare, 2011; Peijnenburg \& Goetze, 2013; Goetze et al., 2017). Despite the lack of obvious geographic barriers, diversity in marine systems can be very high. The shallow-waters of the tropical latitudes, for example, are amongst the biologically most diverse ecosystems, in some cases rivalling the biodiversity seen in tropical rain forests (ReakaKudla, 1997; Plaisance et al., 2011; Fisher et al., 2015). Some authors therefore hypothesised that speciation with gene flow plays a larger role in marine systems compared to terrestrial ecosystems (Miglietta et al., 2011; Bowen et al., 2013). Here, we review potential cases of speciation with gene flow in marine systems. We discuss and compare the potential mechanisms driving divergence with gene flow among different case studies. We further discuss gaps in the current state of knowledge and suggest directions for future research on speciation with gene flow in marine systems.

\section{Mechanisms of speciation with gene flow}

Mathematical models of speciation with gene flow mostly follow a similar pattern. Disruptive 
selection in an initially panmictic population results in non-random mating and reproductive isolation within that population (Maynard Smith, 1966; Bolnick \& Fitzpatrick, 2007). With disruptive selection being the driver of divergence, speciation with gene flow can in most cases be considered a special case of ecological speciation, as defined by Schluter (2009). It should be noted though that ecological factors and selection are likely to play a role in other mechanisms of speciation as well (Schilthuizen, 2000; Schilthuizen et al., 2006; Sobel et al., 2010). Disruptive selection on its own is, however, not sufficient to maintain reproductive isolation, as random mating will counteract the genetic diversification and reproductive isolation between subpopulations (Bolnick \& Fitzpatrick, 2007). Assortative mating, for example through mate selection or (sub-) habitat differentiation, is required. Recombination between the assortment trait and the selected trait would, however, prevent the evolution of reproductive isolation through disruptive selection (Felsenstein, 1981), which has been coined the 'selection-recombination antagonism' by Rice (1984). Selection should therefore either indirectly, in linkage disequilibrium, or directly affect the assortment trait causing non-random mating for the evolution of reproductive isolation to occur (Kirkpatrick \& Ravigné, 2002). Besides evidence for (historical) gene flow after the divergence between populations, evidence for disruptive selection, assortative mating, and a link between the selected trait and the assortment trait should be present in the studied populations to infer speciation with gene flow.

We will evaluate cases of potential (incipient) speciation with gene flow against six criteria. First, to identify cases of incipient speciation we ask:

1. Are populations reproductively isolated? This is the second criterion of Coyne \& Orr (2004) for speciation in sympatry. While the fate of cases of incipient speciation is not known, studying systems at different stages of speciation could provide a better insight into the mechanisms playing a role during the process of speciation (Butlin et al., 2008). It is likely that some hybridisation will occur among closely related species. The threshold value of hybridisation, below which reproductive isolation is considered to be 'complete', is impossible to determine exactly. Determining such a value will always be arbitrary, trying to classify the continuous scale of hybridisation, from panmixia to full reproductive isolation, into discrete categories. Additionally, data on hybridisation are often scarce in less well-studied species, and therefore difficult to quantify and compare among species. This makes assessing this criterion problematic. However, the effect of this lack of data will not affect the conclusions of this study, as the next criteria are more relevant to the question of the frequency of ecological speciation with gene flow.

Secondly, the four requirements for speciation with gene flow are assessed:

2. Is there (potential for) disruptive selection?

3. Do populations mate assortatively in sympatry?

4. Is the selected trait linked to the assortment trait?

5. Is there evidence for gene flow between populations at the time of divergence?

These criteria are derived from mathematical models of speciation with gene flow (e.g., Maynard Smith, 1966; Kawecki, 1997; Doebeli \& Dieckmann, 2000). The second, third, and fourth criterion were also used by Rundle \& Nosil (2005) in their review of ecological speciation. The fifth criterion, which directly tests for the occurrence of gene flow during divergence, was added to exclude cases where ecological speciation occurred without gene flow, in geographically separated populations (Schluter, 2009). However, this criterion is 
problematic to meet, as it requires the reconstruction of the degree of historical gene flow based on data from modern populations.

Finally, the geographic context of speciation will be discussed:

6. Do geographic ranges of populations overlap?

This is the first criterion of Coyne \& Orr (2004) for speciation in sympatry. The geographic context of speciation (sympatry versus allopatry) and the degree of gene flow may often be correlated in the field but are not identical and should therefore not be used interchangeably. While the geography of speciation cannot be considered an evolutionary process (Fitzpatrick et al., 2008, 2009), the question how geography influences gene flow is still interesting (Mallet et al., 2009; Maas et al., 2018), especially in marine systems without clear geographic borders, even though recent studies show that in the open ocean geographic as well as bathymetric barriers might be more common than previously assumed (Weiner et al., 2012; Peijnenburg \& Goetze, 2013).

\section{3 \\ Potential cases of speciation with gene flow}

We searched the literature for potential cases of ecological speciation with gene flow in marine systems. Studies were included if evidence for gene flow between sister clades (either conspecific, genetically diverged populations or distinct species), was found or if sister clades occur in sympatry.

The literature search yielded a list of 33 marine taxa across a wide taxonomic range in which ecological divergence with gene flow potentially may have played a role (table 1 , more extensive data are in supplementary table $\mathrm{S} 1$ ). Most of these cases involve tropical taxa (21 out of 33 cases) with one additional case involving deep-water species from the tropical latitudes. Almost all cases deal with animal taxa, only one instance of ecological speciation in non-animals was found (a brown alga). Ecological speciation was found scattered across the animal kingdom (figs. 1-2). Breaking the list down further based on taxonomy, fishes are represented with eleven cases, distributed over ten families. The other instances involve six gastropods, two species complexes of shrimp, three stony corals, two octocorals, a barnacle, a sponge, a polychaete worm, an amphipod, a crab, a sea star, a bivalve, and a sea snake. The identified cases differ in the phylogenetic level on which nonallopatric divergence is thought to have occurred, from recently diverged conspecific host races (e.g., Fritts-Penniman, 2016) to older divergence among species within a genus (e.g., Jones et al., 2003).

\subsection{Criterion 1: Reproductive isolation}

The degree of reproductive isolation varies among the taxa. In 16 of the 33 cases of potential ecological speciation with gene flow, diverged populations are described as a single species. Some degree of reproductive isolation has been reported within three of these taxa. Prezygotic (Rolán-Alvarez et al., 1999) and possibly some postzygotic reproductive isolation (Hull et al., 1996; but see Johannesson et al., 2010) has been observed between ecotypes of the intertidal gastropod Littorina saxatilis (Olivi, 1792), as well as a reduced gene flow over hybrid zones between ecotypes (Panova et al., 2006). Limited gene flow was detected between the depth-segregated ecotypes of the scleractinian coral Favia fragum (Esper, 1793) (Carlon \& Lippé, 2011), as well as in depth-segregated populations of the scleractinian coral Montastraea cavernosa (Linnaeus, 1767) (Serrano et al., 2014). Besides these three taxa, assortative mating between populations, for example as a result of different host-associations in philopatric species, is 

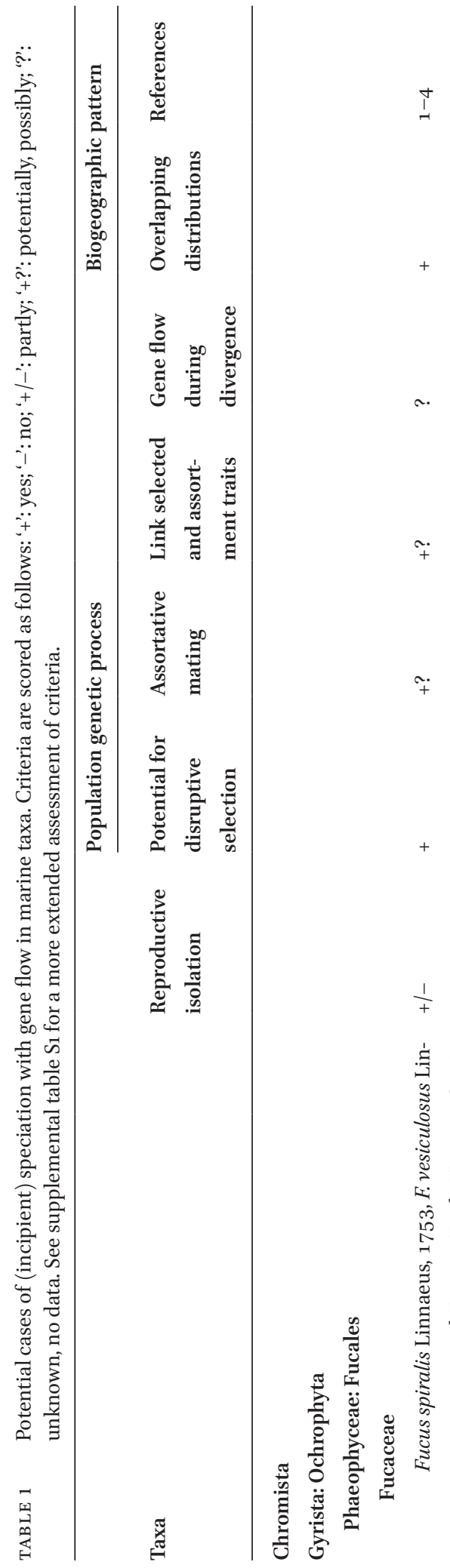

$i$

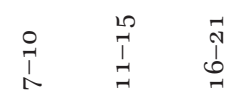

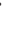

$+$

$\ddot{+}$

$\frac{1}{+}$

$\dddot{+}$

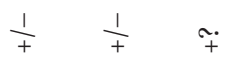

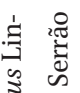

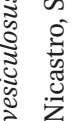

กิ

$\stackrel{-1}{5}$

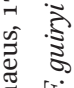

葛这

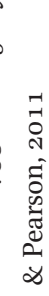
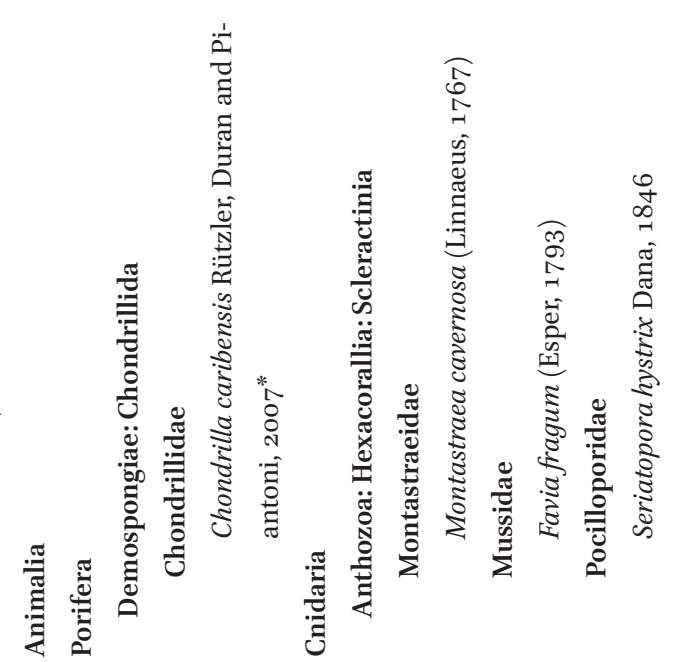


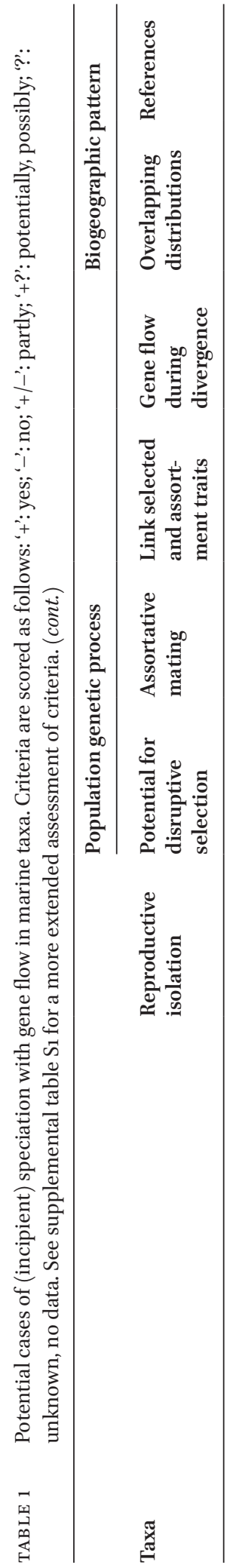

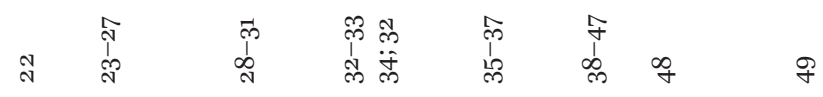




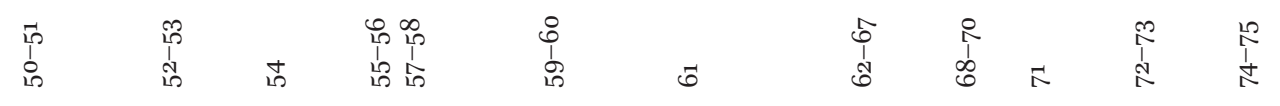

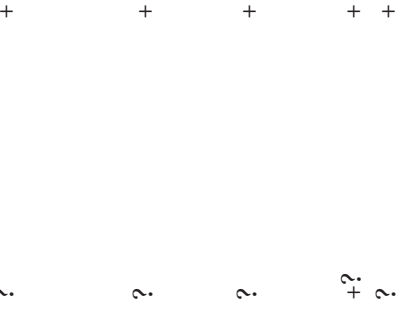

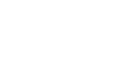

\begin{tabular}{|c|c|c|}
\hline$\underset{+}{q}$ & $\stackrel{+}{+}$ & $\ddot{+}$ \\
\hline q. & r. & $\tilde{+}$ \\
\hline
\end{tabular}

$\stackrel{+}{+}+++$
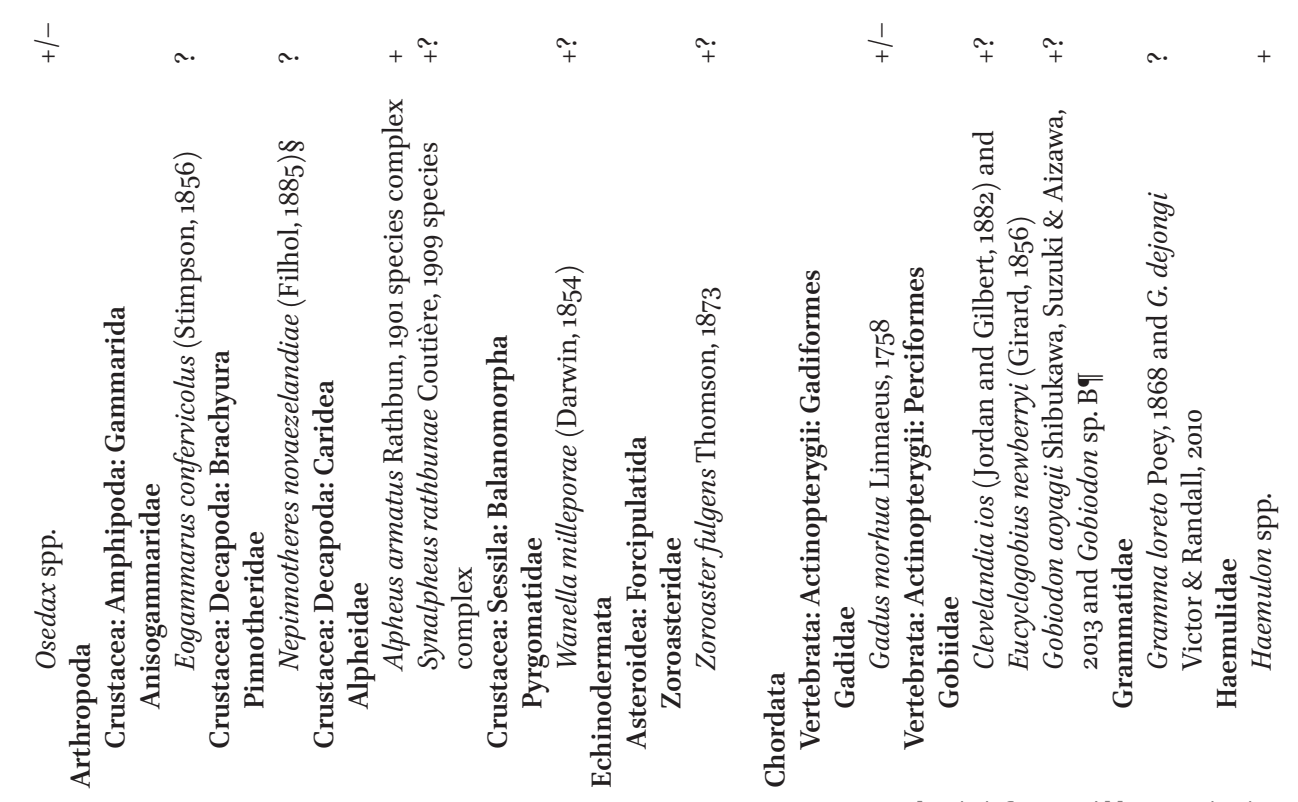


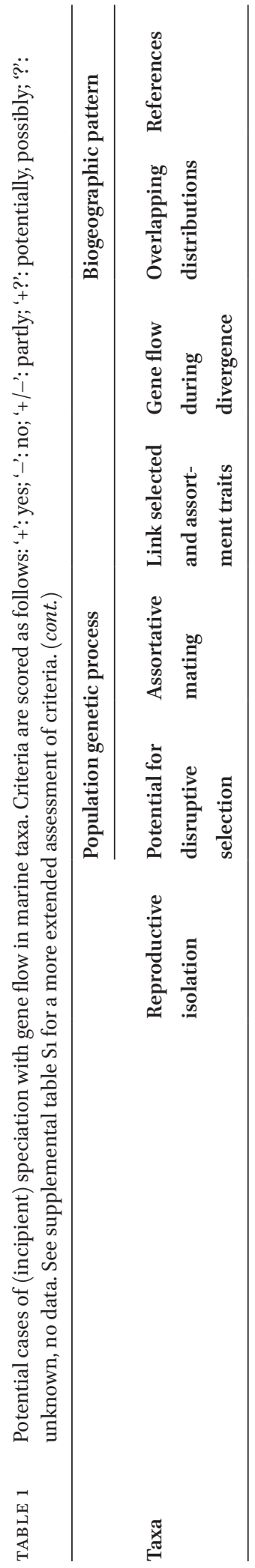

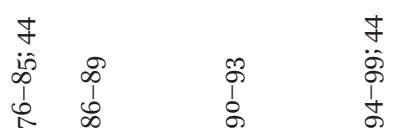

के

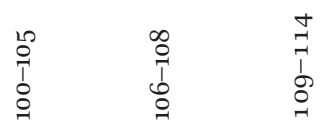




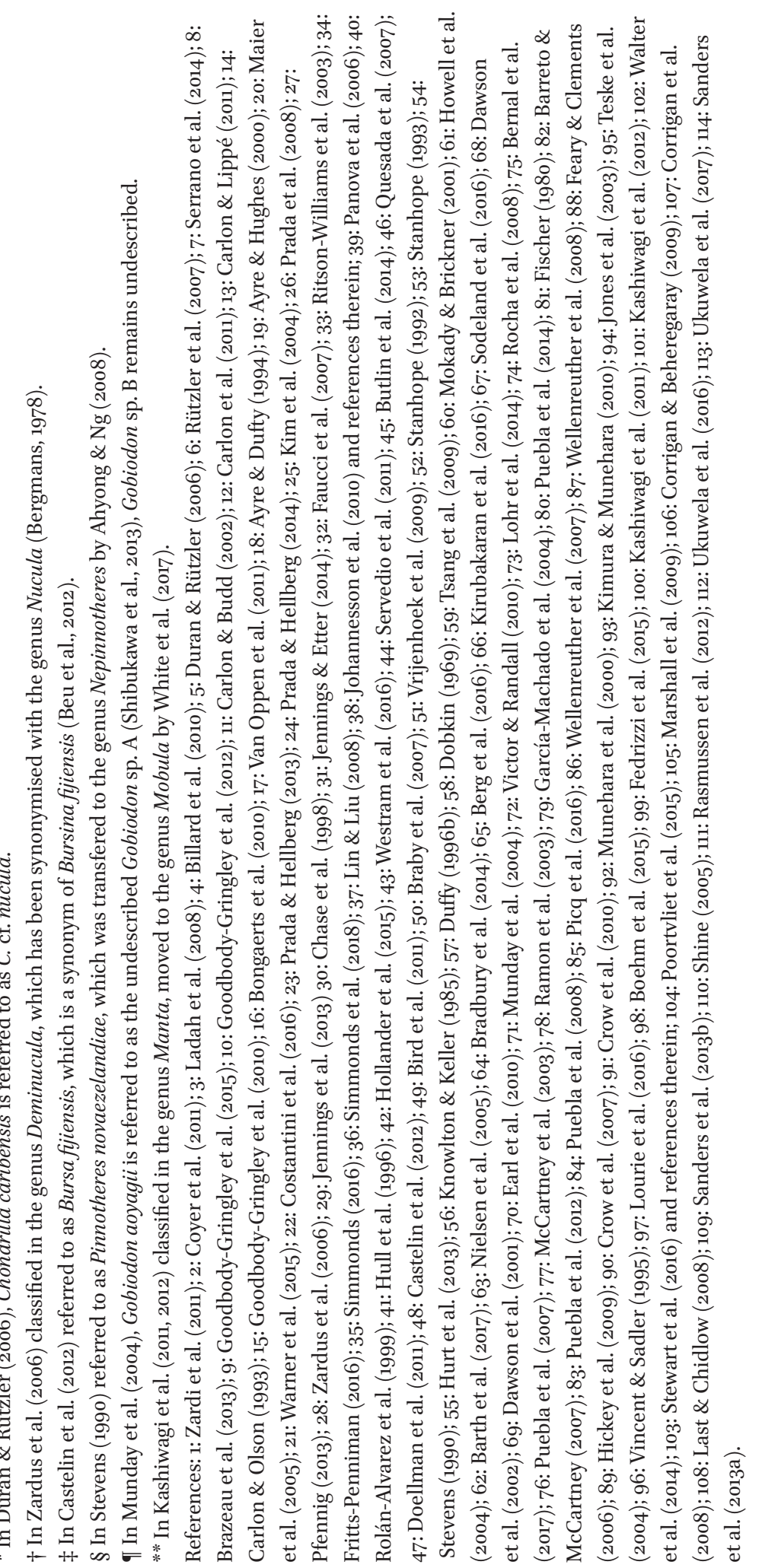




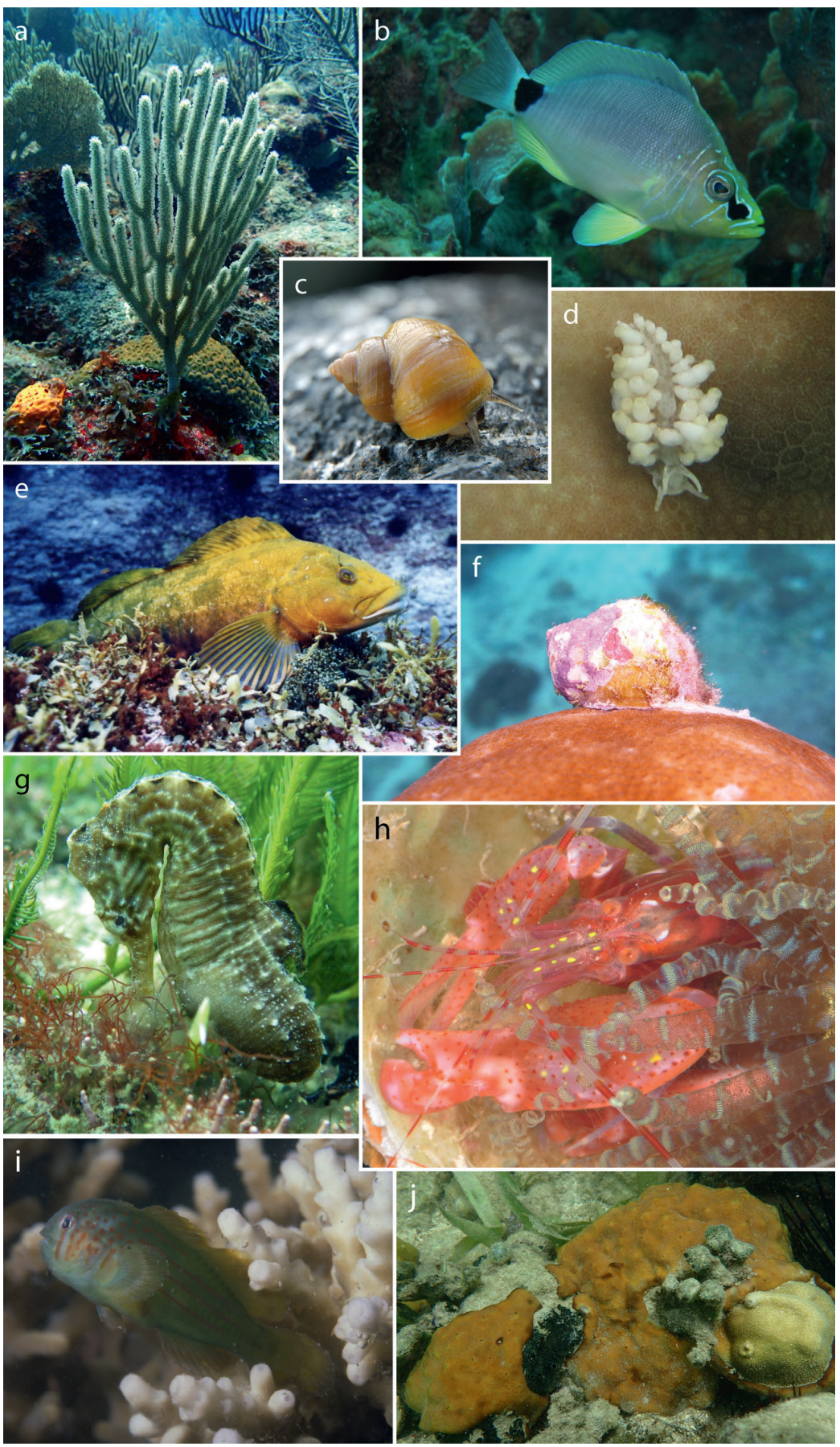

FIGURE 1 Examples of some species which potentially arose through ecological speciation with gene flow. The octocoral Eunicea flexuosa (a; photo by Y.W. Lau), the Caribbean hamlet Hypoplectrus unicolor (b; photo by O. Puebla), the intertidal gastropod Littorina saxatilis (c; photo by P. Larsson), the nudibranch Phestilla minor (d; photo by A. Fritts-Penniman), the Japanese greenling Hexagrammos otakii (e; photo by Z. Kanamoto), the corallivorous gastropod Coralliophila violacea (f; photo by S.E. Simmonds), the seahorse Hippocampus erectus (g; photo by E. Rose), the snapping shrimp Alpheus armatus (h; photo by A. Anker), the undescribed, coral-associated goby Gobiodonosp. Ba(déphhoto by PIL. Munday), rand the 21: 23AM Caribbean sponge Chondrilla caribensis (j; photo by N.J. de Voogd). 


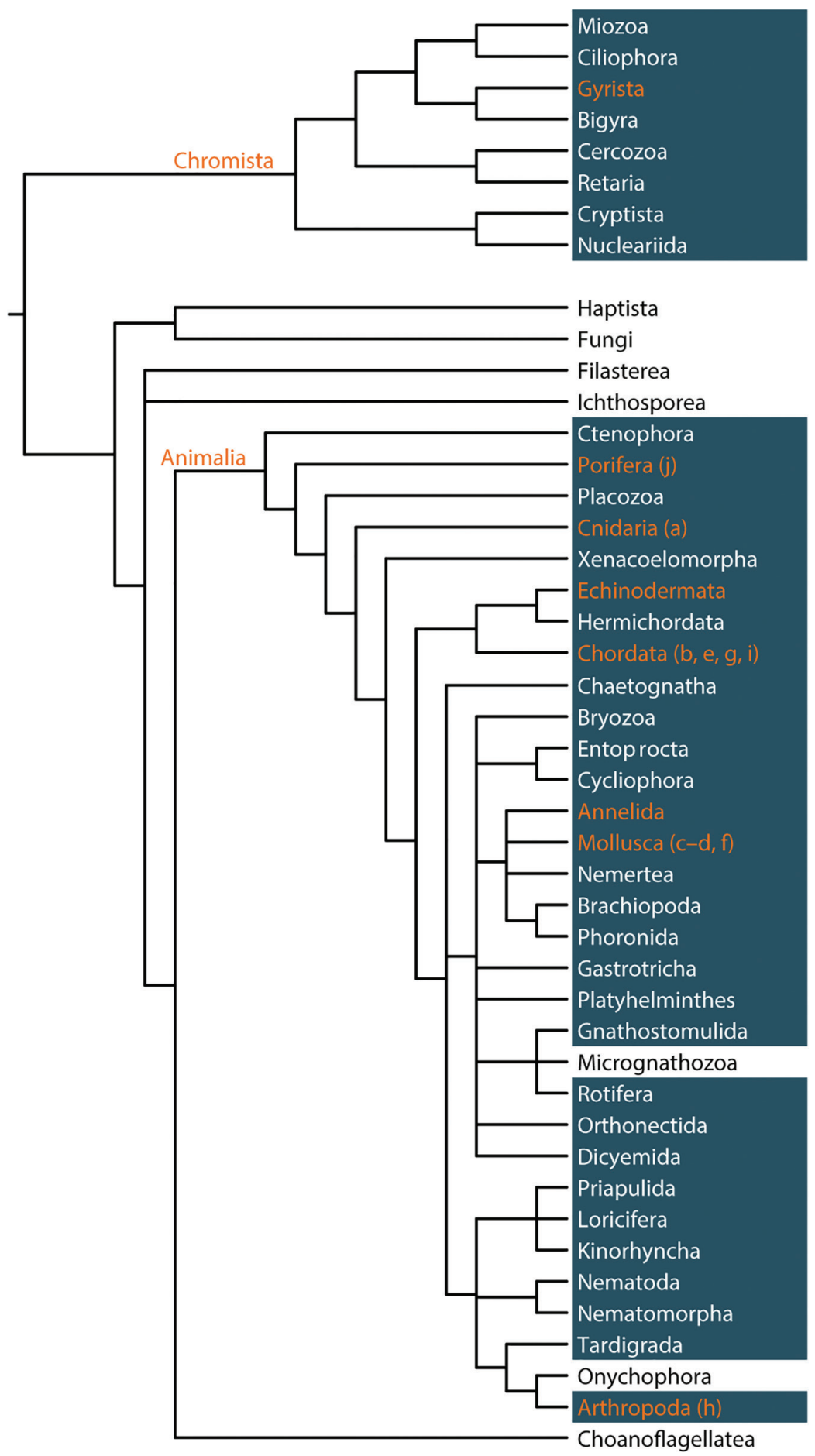

FIGURE 2 Cladogram of the hypotheses of Animalia (after Dunn et al., 2014) and Chromista (after CavalierSmith, 2018) phylogenies. Animalia and Chromista clades in which marine species have been described, are marked blue, with clades in which potential cases of ecological speciation with gene flow have been identified in orange. Letters refer to examples of species shown in fig. 1. 
seen in many of the taxa discussed here and leads to some of the cases of prezygotic reproductive isolation (supplementary table $\mathrm{S} 1$; see also below).

In 17 taxa, diverged populations are described as separate species, with direct evidence for reproductive isolation found in three taxa. Prezygotic isolation was found in the four shrimp species of the Alpheus armatus Rathbun, 1901 species complex (Knowlton \& Keller, 1983, 1985), the triplefin fishes $R u$ anoho decemdigitatus (Clarke, 1879) and the smaller R. whero Hardy, 1986 (Wellenreuther et al., 2008). Prezygotic reproductive isolation is thought to be nearly complete between the sympatric greenlings Hexagrammos otakii Jordan \& Starks, 1895 and H. agrammus (Temminck \& Schlegel, 1843) (Munehara et al., 2000; Crow et al., 2010). Postzygotic isolation was not observed between $H$. otakii and H. agrammus. This pattern (high prezygotic and low postzygotic isolation) is reversed between the two sympatric species and the allopatric H. octogrammus (Pallas, 1814) (Crow et al., 2010), which in itself is a strong signature for ecological speciation with gene flow between $H$. otakii and H. agrammus (Via, 2001; Crow et al., 2010).

Rates of hybridisation can give some insight into the degree of reproductive isolation. Spawning among Caribbean hamlet species of the genus Hypoplectrus Gill, 1861 is rare, but a low rate of hybridisation has been reported (Ramon et al., 2003; García-Machado et al., 2004; Puebla et al., 2007). Walter et al. (2014) recorded a hybrid of the manta rays Mobula alfredi (Krefft, 1868) and M. birostris (Walbaum, 1792) (both species used to be classified in the genus Manta Bancroft, 1829, see White et al., 2017).

Finally, hybridisation can result in incongruent gene trees, as mitochondrial DNA is generally more susceptible to introgression compared to nuclear DNA (Takahata\& Slatkin,
1984; Moore, 1995; Sang \& Zhong, 2000; Funk \& Omland, 2003; Coyne \& Orr, 2004; De Vienne et al., 2013; Cruaud \& Rasplus, 2016). Several studies indirectly inferred the presence or absence of reproductive isolation based on gene trees, or patterns of introgression (supplementary table $\mathrm{S}$ ).

\subsection{Criterion 2: Disruptive selection}

Evidence for disruptive selection was found in eight out of the 33 cases. This evidence mostly comes from $F_{\mathrm{ST}}$ outlier tests (Lewontin \& Krakauer, 1973; Lotterhos \& Whitlock, 2014). Puebla et al. (2014) found one single nucleotide polymorphism (SNP), located in a region of Hox genes, to be under disruptive selection in three species of hamlets: Hypoplectrus puella (Cuvier, 1828), H. nigricans (Poey, $185^{2}$ ), and H. unicolor (Walbaum, 1792). Bernal et al. (2017) identified four independent loci that might have been involved in the divergence between the sympatric sister pair of grunt species Haemulon maculicauda (Gill, 1862) and $H$. flaviguttatum Gill, 1862, which differ in habitat use. Several studies found $F_{\text {ST }}$ outliers in ecotypes of the intertidal gastropod Littorina saxatilis from different localities using a wide range of methods (Westram et al., 2016 and references therein). The $L$. saxatilis ecotypes are a well-studied model system of speciation, in which selection by crab predation and wave exposure acts on body size and shape (Janson, 1983; Johannesson, 1986; Rolán-Alvarez et al., 1997; Johannesson et al., 2010; Le Pennec et al., 2017). These data suggest that traits on which selection acts are highly polygenic (Hollander et al., 2015; Westram etal., 2016). Finally, Carlon \& Budd (2002) found strong divergence between depth-segregated morphotypes of the coral Favia fragum on an allozyme locus encoding the phosphoglucomutase enzyme, indicating potential disruptive selection as well. Carlon et al. (2011) found significant heritability in corallite architecture, 
which varies between morphotypes, confirming a genetic basis for the differences between the morphotypes.

The link between function of these genes potentially under disruptive selection and the (ecological) differences between the diverged species is not obvious. In case of hostassociated divergence, a well-known driver of ecological speciation (e.g., Drès \& Mallet, 2002; Matsubayashi et al., 2010), this link may be easier to establish. Indeed, two studies did find evidence for disruptive selection on genes potentially related to survival on new host species. In the corallivorous gastropod Coralliophila violacea (Kiener, 1836 ), a gene involved in the control of xenobiotic detoxification pathway gene expression, which may be related to the neutralisation of host-specific metabolites, as well as four other genes involved in metal binding ions, were found to be potentially under disruptive selection (Simmonds, 2016). Functionally similar genes are thought to play a role in ecological speciation in insects (Soria-Carrasco et al., 2014; Simon et al., 2015; Simmonds, 2016). Fritts-Penniman (2016) identified a gene encoding a lysosome membrane protein in the coral-associated nudibranch Phestilla minor Rudman, 1981 as potentially being under disruptive selection, which may be involved in the treatment of host coral nematocysts in the nudibranch's digestive tract.

Results from $F_{\mathrm{ST}^{-}}$outlier tests such as these should be interpreted carefully. Several studies reported the prevalence of false positives (Beaumont \& Balding, 2004; Narum \& Hess, 2011), especially when populations are isolated by distance or have undergone range expansions (Lotterhos \& Whitlock, 2014), or in species living in long, linearly shaped habitats such as river, deep-sea, or coastal ecosystems (Bierne et al., 2013; Fourcade et al., 2013). Using a negative control by randomizing the data (Puebla et al., 2014) and searching for consistent outliers across geographically distant populations or across different datasets (Puebla et al., 2014; Fritts-Penniman, 2016) may reduce the rate of false positives. Including a large dataset of putatively neutral loci also increases the performance of $F_{\mathrm{ST}^{-}}$-outlier tests (Lotterhos \& Whitlock, 2014).

Mechanisms other than disruptive selection may result in $F_{\mathrm{ST}}$-outliers. Loci involved in intrinsic (i.e., independent of ecology) genetic incompatibilities can easily and arbitrarily associate with locally adapted and neutral loci, especially in case of fine-grained environmental heterogeneity (e.g., in case of populations differing in host use), or when ecological selection is weak (Bierne et al., 2011). Even though this association results in a coupling between endogenous and exogenous barriers and may be responsible for the majority of $F_{\mathrm{ST}}$ outliers found in genome scans, this alternative explanation is mostly neglected in genome scans looking for signs of disruptive selection in the context of ecological speciation with gene flow (Bierne et al., 2011). The candidate loci potentially under disruptive selection discussed above (Puebla et al., 2014; Simmonds, 2016; Bernal et al., 2017) might therefore not be driving ecological speciation. Instead, the loci may be involved in or linked to genetic incompatibilites (Bierne et al., 2011; Puebla et al., 2014).

Genomic data may provide further insights in the mechanisms driving divergence between populations. In the case of the Atlantic cod Gadus morhua Linnaeus, 1758, several genes involved in adaption to low salinity, temperature, and oxygen levels have clustered together in discrete genomic regions. These regions, which likely represent large chromosomic inversions, are likely involved in local adaptation and in the divergence of fjord and offshore populations (Berg et al., 2015, 2016; Kirubakaran et al., 2016; Sodeland et al., 2016; Barth et al., 2017). Genes within these regions 
are tightly linked and the lack of recombination may enable local adaptation in spite of high population connectivity (Barth et al., 2017).

In the other taxa, no evidence for specific genetic loci under disruptive selection has been found. However, disruptive selection on, for example, habitat choice (Levene, 1953; Maynard Smith, 1966; Gavrilets, 2006; Bolnick \& Fitzpatrick, 2007) could potentially play a role in most cases. Transplant experiments on the depth-segregated ecotypes of the Caribbean octocoral Eunicea flexuosa (Lamouroux, 1821) showed for instance a decrease in survival rate of ecotypes in non-native depth ranges, suggesting strong disruptive selection (Prada \& Hellberg, 2013). Similar differences in hostor habitat-associations are found in the majority of discussed taxa (supplementary table $\mathrm{S} 1$ ). The genetic mechanisms underlying these differences, as well as the strength of any disruptive selection, remain unknown.

\section{$3 \cdot 3$}

Criterion 3 and 4: Assortative mating and the link between the selected and assortment trait

Disruptive selection is not enough for ecological speciation to occur, both assortative mating and a link between the trait under disruptive selection and the assortment trait are required for reproductive isolation to evolve. In some cases, a single trait is both subjected to disruptive selection and contributing to assortative mating. The selection-recombination antagonism does not apply to these traits, which have been called 'magic traits' (or 'speciation traits') (Gavrilets, 2004; Servedio et al., 2011). While pleiotropy between selected and assortment trait was originally thought to be unlikely (Maynard Smith, 1966), such traits seem to be less rare than previously assumed (Servedio et al., 2011).

In four of the 33 cases, disruptive selection on body size may coincide with assortative mating based on body size. In seahorses, selective constraints on body size, imposed by malepregnancy, combined with size-assortative mating, as observed in seahorse populations (Vincent \& Sadler, 1995; Jones et al., 2003), may have led to speciation in two pairs of sympatric species, Hippocampus erectus Perry, 1810 and $H$. zosterae Jordan \& Gilbert, 1882 from the western Atlantic, and $H$. abdominalis Lesson, 1827 and $H$. breviceps Peters, 1869 from the Indo-West Pacific, which differ in body size (Jones et al., 2003). Similarly, body-size diverged as a result of diet specialisation in macro- and microcephalic ecotypes in species of the sea snake genus Hydrophis Latreille [in Sonnini \& Latreille], 1801, and, being known as a mating cue in some sea snake species (Shine, 2005), could have induced assortative mating as well (Sanders et al., 2013 b). In these two cases however, only observational data is available and disruptive selection or assortative mating could act on or be based on a correlated, unknown trait instead of body size or colour pattern (Servedio et al., 2011). Sizeassortative mating has been observed between ecotypes of the gastropod Littorina saxatilis (Johannesson et al., 1995; Hollander et al., 2005; Johannesson et al., 2008, 2010), which, as discussed above, are also subject to disruptive selection based on body size (Johannesson et al., 2010). Experimental data on assortative mating and disruptive selection is available in this case (Rolán-Alvarez, 2007; Johannesson et al., 2010), which makes the case for body size as a (single) trait driving divergence between $L$. saxatilis ecotypes stronger (Servedio et al., 2011). Size-assortative mating, combined with potential disruptive selection on body size driving differences in habitat use, has also been observed between the triplefin fishes Ruanoho decemdigitatus and R. whero (Wellenreuther et al., 2008).

Like body size, colour pattern has potentially been subject to both disruptive selection 
and assortative mating in at least one of the 33 cases discussed here. Colour-assortative mating has been observed within Caribbean hamlets (Hypoplectrus spp.) (Fischer, 1980; Barreto \& McCartney, 2007; Puebla et al., 2007, 2012), in which aggressive mimicry, where the fish mimic the colour pattern of non-predatory fish, may have resulted in disruptive selection on the colour pattern (Puebla et al., 2007). However, only observational data is available (Servedio et al., 2011), and it is unknown if the genomic region to be found under disruptive selection in hamlets (Puebla et al., 2014), as described above, is linked to the colour pattern of the fish. Colour patterns are a diagnostic trait in snapping shrimps of the $A l$ pheus armatus complex as well (Knowlton \& Keller, 1985; Hurt et al., 2013), and may induce assortative mating (Knowlton \& Keller, 1983, 1985), as it appears to do in the basslets Gramma loreto Poey, 1868 and G. dejongi Victor \& Randall, 2010 (Victor \& Randall, 2010; Lohr et al., 2014). Colour pattern could therefore potentially have played a role in the divergence of these species, but the available data is not enough to draw any conclusions.

Body size and colour pattern can be considered 'classic' magic traits, meaning that disruptive selection is hypothesized to act on a mating cue (Servedio et al., 2011). In case of a

a

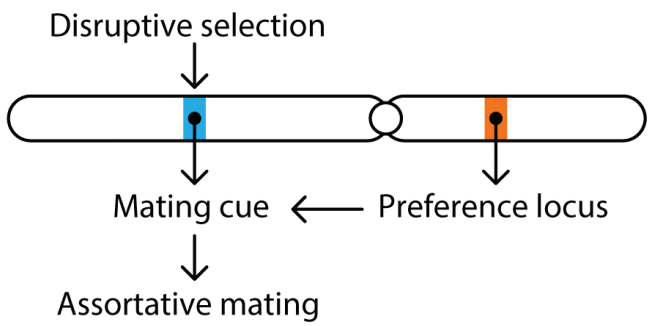

classic magic trait, the mating cue is targeted by a preference locus elsewhere in the genome (fig. 3a). Disruptive selection on a classic magic trait is in some cases sufficient for the evolution of reproductive isolation, such as in species displaying self-referent phenotype matching, using one's own cues as a referent for recognizing kin (Mateo, 2010), while in other cases (specifically, in theoretical, twoallele systems of speciation, see Felsenstein, 1981; Gavrilets, 2004), disruptive selection on the preference locus is required as well (Servedio et al., 2011). Whether speciation in the taxa described above follows the theoretical oneor two-allele system is not known.

In contrast to classic magic traits, 'automatic' magic traits do not require a preference locus (fig. 3b). Disruptive selection on an automatic magic trait, in theory, automatically leads to assortative mating instead (Servedio et al., 2011). For example, divergence in the mating system of macroalgae Fucus spiralis Linnaeus, 1753, F. guiryi Zardi, Nicastro, Serrão and Pearson, 2011, and $F$. vesiculosus Linnaeus, 1753 , as well as a difference in timing of gamete release, may have induced assortative mating and driven the divergence among these species (Ladah et al., 2008; Billard et al., 2010; Zardi et al., 2011).

b

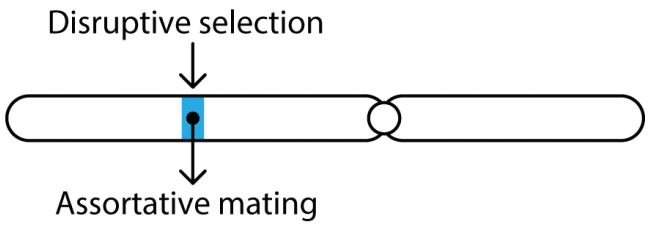

FIGURE 3 Genetic mechanisms of single traits driving divergence. Disruptive selection acting on a mating cue (e.g., colour pattern or body size) targeted by a preference locus elsewhere in the genome ('classic magic trait', after Servedio et al., 2011) results into assortative mating (a). In case of habitat or host differentiation and mating on the host species, disruptive selection may directly lead to assortative mating (b), without the need for a preference locus ('automatic magic trait'). Figures after Servedio et al. (2011). 
Species where mating occurs on a host species or within a preferred habitat (i.e., habitat fidelity) are another example where selection directly affects the assortment trait (Kirkpatrick \& Ravigné, 2002; Bolnick \& Fitzpatrick, 2007). A shift to a novel habitat or host species may pleiotropically bring about prezygotic reproductive isolation and could ultimately result in speciation (Drès \& Mallet, 2002; Kirkpatrick \& Ravigné, 2002; Bolnick \& Fitzpatrick, 2007; Forbes et al., 2017). Host or habitat preference can therefore be considered an automatic magic trait (Servedio et al., 2011). Differences in habitat or host associations are found in 27 out of the cases discussed here (table 1; supplementary table $\mathrm{S} 1$ ).

While differences in habitat-associations are observed in the majority of the taxa discussed here, data on the strength of habitat or host preference is scarce, and the genetic mechanism of habitat preference remains unknown in all of the cases discussed here. Experimental evidence for host preference is only available from the four snapping shrimp species of the Alpheus armatus species complex (Knowlton \& Keller, 1985), the amphipod Eogammarus confervicolus (Stimpson, 1856) (Stanhope et al., 1992), and the corallivorous gastropod Coralliophila violacea (Fujioka \& Yamazato, 1983; Simmonds et al., 2018). Hostpreference was not perfect in either of these cases, suggesting that while in theory magic traits might induce full assortative mating (and therefore reduce gene flow to zero), in the real world a single trait may not be able to do so.

Habitat-preference is not required to induce (some) assortative mating in some cases. Disruptive selection over gradients of multiple environmental variables (such as temperature, oxygen concentration, and salinity) may have induced assortative mating in the Atlantic cod Gadus morhua (Berg et al., 2016; Kirubakaran et al., 2016; Sodeland et al.,
2016; Barth et al., 2017; but see Neuenfeldt et al., 2013). On much smaller geographic scales, disruptive selection over a depth gradient, resulting in immigrant inviability, could induce almost complete assortative mating between depth-segregated ecotypes of the octocoral Eunicea flexuosa, as the cumulative decrease in survival from the time of larval settling to the high age of reproductive isolation (Beiring \& Lasker, 2000) results in a decrease of 'mismatched' genotypes over time, even when random settling of larvae is assumed (Pfennig, 2013; Prada \& Hellberg, 2013). Similar mechanism could potentially play a role in the depth-segregated morphotypes of the octocoral Eunicella singularis (Esper, 1791) studied by Constantini et al. (2016) and the Alpheus armatus species complex (Hurt et al., 2013), but more research is required to confirm this hypothesis.

In three cases, specifically the depthsegregated morphotypes of the broadcast spawning, scleractinian corals Montastraea cavernosa and Seriatopora hystrix Dana, 1846 studied by Serrano et al. (2014) and Bongaerts et al. (2010) respectively, and the Hawaiian limpets of the genus Cellana Adams, 1869 studied by Bird et al. (2011) the presence of a mechanism inducing assortative mating is not clear.

\subsection{Criterion 5: Gene flow during divergence}

The main challenge of inferring speciation with gene flow is the rejection of the alternative hypothesis of speciation in isolation. Specifically, distinguishing speciation with gene flow from gene flow after secondary contact is a challenging task (Gaggiotti, 2011; Strasburg \& Rieseberg, 2011; Feder et al., 2013; Strasburg \& Rieseberg, 2013).

Coalescence-based 'isolation-migration' (IM) models (Hey \& Nielsen, 2004) are used widely to assess gene flow between populations (e.g., Won \& Hey, 2005; Niemiller et al., 
2008). IM models, or similar Bayesian models for inferring gene flow, were used in six out of the 33 taxa discussed here. Evidence for gene flow after divergence was found among snapping shrimps of the Alpheus armatus species complex (Hurt et al., 2013), between two species of manta rays (Mobula spp.) (Kashiwagi et al., 2012), among four closely related sea snakes of the genus Hydrophis (Sanders et al., 2013 b), between depth-segregated ecotypes of the octocoral Eunicea flexuosa (see Prada \& Hellberg, 2013), between depth-segregated populations of the deep-sea bivalve Nucula atacellana Schenck, 1939 (Jennings et al., 2013), and between depth-segregated populations of the scleractinian coral Montastraea cavernosa (see Serrano et al., 2014). Three of these studies (Kashiwagi et al., 2012; Prada \& Hellberg, 2013; Sanders et al., 2013b) used likelihood ratio tests within their IM approach and found higher support for a model including gene flow compared to models without any gene flow. IM models, as well as related methods as used by Serrano et al. (2014), cannot, however, assess heterogeneity in gene flow over time (Niemiller et al., 2010; Gaggiotti, 2011; Sousa et al., 2011; Strasburg \& Rieseberg,2011,2013). Therefore, secondarycontact after speciation without gene flow cannot be precluded based on these results (Hurt et al., 2013).

To test complex evolutionary scenarios, explicitly incorporating secondary contact, other methods are required. Approximate Bayesian computation (ABC; Beaumont et al., 2002; Hickerson et al., 2006; Beaumont, 2010; Csilléry et al., 2010) is a powerful method to test such complex hypotheses of divergence, which could be used in this context (Sousa et al., oog; Bird et al., 2012; Sousa et al., 2012; Hurt et al., 2013). Using ABC, Butlin et al. (2014) found higher support for a model of parallel, repeated divergence with gene flow between the ecotypes of the intertidal gastropod
Littorina saxatilis compared to a model assuming gene flow through secondary contact.

The ABC-approach comes however with its own caveats, ABC models have been criticised by multiple authors (e.g., Templeton, 2009, 2010; Robert et al., 2011). As ABC only compares a subset of all possible models, which introduces subjectivity in the selection of models to be tested, and introduces the risk of not including the true model (Templeton, 2009; but see Beaumont et al., 2010; Csilléry et al., 2010,). Additionally, the use of insufficient summary statistics, used to compare simulation data with actual data, may lead to an unknown loss of information (Robert et al., 2011).

Data on historical gene flow is lacking in the other taxa. Ongoing gene flow, described above, is not necessarily evidence for speciation with gene flow, as, again, hybridisation can be the result of secondary contact. The ecology of species may give some clues as to whether gene flow was likely during divergence. The dispersal potential of species can strongly affect the potential degree of gene flow among populations. The potential for gene flow during divergence may be higher in species that do have a pelagic larval stage and lack genetic structuring over distance (Fitzpatrick et al., 2008; Krug, 2011). Biophysical modelling of larval dynamics, for example, showed a potential high connectivity between locally adapted populations of Atlantic cod Gadus morhua (see Barth et al., 2017). Additionally, in panmictic, sympatric sister taxa with a long, pelagic larval stage, panmixia during divergence seems a reasonable hypothesis (Fitzpatrick et al., 2008; Krug, 2011). For example, low phylogeographic structuring was found east of the Sunda Shelf in both the corallivorous gastropod Coralliophila violacea (Lin \& Liu, 2008; Simmonds, 2016) and the nudibranch Phestilla minor (but see Faucci et al., 2007) (Fritts-Penniman, 2016), both of which have a long, pelagic larval stage (Demond, 
1957; Taylor, 1975; Ritson-Williams et al., 2007, 2009; Lin \& Liu, 2008). A lack of phylogeographic structure was found in several other taxa (table 1; supplementary table S1).

An abbreviated development without a pelagic larval stage on the other hand or localized recruitment or self-recruitment despite a long dispersal potential would decrease the likelihood of gene flow during divergence of the species or habitat races (Fitzpatrick et al., 2008). Abbreviated development occurs in, for example, the shrimps of the Synalpheus rathbunae Coutière, 1909 species complex (Dobkin, 1965, 1969), the brooding coral Favia fragum (Carlon \& Olson, 1993; Carlon \& Budd, 2002; Goodbody-Gringley et al., 2010; Carlon \& Lippé, 2011), and potentially in the bivalve-associated pea crab Nepinnotheres novaezelandiae (Filhol, 1885) (= Pinnotheres novaezelandiae, see Ahyong \& Ng, 2008), as is described in other members of the family Pinnotheridae De Haan, 1833 (Goodbody, 1960; Stevens, 1990; Bolaños et al., 2005). In the oceanic manta ray Mobula birostris (see Stewart et al., 2016), the broadcast-spawning scleractinian coral Montastraea cavernosa (Goodbody-Gringley et al., 2012; Brazeau et al., 2013), or the snapping shrimps of the $A l$ pheus armatus species complex (Knowlton \& Keller, 1986), localized recruitment has been observed, even though evidence for gene flow among species was found in the latter case (Hurt et al., 2013).

\subsection{Criterion 6: Geographic context of speciation}

While the geographic context of speciation is related to the degree of gene flow among populations, both concepts are distinct and should not be confused (Fitzpatrick et al., 2008, 2009). The geographic distribution may give a clue about whether speciation occurred in sympatry, regardless of the evolutionary mechanisms and the degree of gene flow among diverging populations. In all but one (the Atlantic cod Gadus morhua; Barth et al., 2017; but see Neuenfeldt et al., 2013) of the cases discussed here, some overlap in geographic range between species or populations can be found. Nested distributions, where the distribution of one species is encompassed by the distribution of its sister species, are hard to explain in a framework of speciation as a result of geographic isolation. Nested distributions were found in five of the 33 taxa discussed here, namely in the Indo-Pacific coral-associated gobies of the genus Gobiodon Bleeker, 1856 (Munday et al., 2004), the seahorses Hippocampus erectus and H. zosterae (see Jones et al., 2003), the basslets Gramma loreto and G. dejongi (Victor \& Randall, 2010; Lohr et al., 2014), sea snakes Hydrophis parviceps Smith, 1935, H. cyanocinctus Daudin, 1803, and $H$. melanocephalus Gray, 1849 (Rasmussen et al., 2012; Sanders et al., 2013b), three Hawaiian limpet species form the genus Cellana (Bird et al., 2011), the deep-sea gastropods Bursina fijiensis (Watson, 1881) (= Bursa fijiensis, see Beu et al., 2012) and Bursa quirihorai Beu, 1987 (Castelin et al., 2012), and the eastern Pacific gobies Clevelandia ios (Jordan \& Gilbert, 1882) and Eucyclogobius newberryi (Girard, 1856) (Dawson et al., 2002).

Of the taxa discussed here, overlap in distribution of pelagic fish that do not differ in habitat, such as the hamlets of the genus $H y$ poplectrus (see Puebla et al., 2007), is closest to 'pure' sympatry (Mallet et al., 20o9). The majority of taxa discussed here differ in either habitat- or host-association, and show 'mosaic' sympatry (table 1; supplementary table $\mathrm{S} 1$ ), where species do not coexist at a local scale, but have a patchy distribution instead (Mallet, 2008; Mallet et al., 2009). Depending on the dispersal potential of species, mosaic sympatry can be correlated with a decrease in gene flow between populations (Fitzpatrick et al., 2008; Mallet et al., 2009). 
Importance of ecological speciation with gene flow in marine systems

The strengths of the arguments for ecological speciation with gene flow vary strongly among the taxa discussed here. A strong case for ecological speciation with gene flow can for example be found among the snapping shrimps of the Alpheus armatus species complex (Hurt et al., 2013) and the sea snakes of the genus Hydrophis (Shine, 2005; Sanders et al., 2013b), in which evidence for historical gene flow has been found. However, as discussed above, secondary contact cannot be excluded. Alternatives to ecological speciation with gene flow cannot be ruled out in the majority of the discussed taxa (Howell et al., 2004; Munday et al., 2004; Faucci et al., 2007; Tsang et al., 2009; Bird et al., 2011; Castelin et al., 2012).

The likelihood of secondary contact compared with divergence with gene flow has only been tested in the intertidal gastropod Littorina saxatilis, in which Butlin et al. (2014) found a higher support for parallel divergence of ecotypes with gene flow using ABC. With evidence for gene flow during divergence, as well as (experimental) evidence for disruptive selection and assortative mating within ecotypes (Johannesson et al., 2010; Servedio et al., 2011; Westram et al., 2016), this is the strongest case for speciation with gene flow discussed here.

Many of the other studies discussed here also provide compelling arguments for speciation with gene flow, such as those studying taxa with nested distributions (Dawson et al., 2002; Jones et al., 2003; Munday et al., 2004; Bird et al., 2011; Castelin et al., 2012; Rasmussen et al., 2012; Sanders et al., 2013b), or in which some evidence for disruptive selection has been found, such as in Caribbean hamlets (Puebla et al., 2014), grunts (Bernal et al., 2017), the corallivorous gastropod Coralliophila violacea (Simmonds, 2016), or the nudibranch Phestilla minor (Fritts-Penniman, 2016). Also, the pattern of pre- and postzygotic isolation in the sympatric Japanese greenlings Hexagrammos otakii and $H$. agrammus compared with their allopatric congener $H$. octogrammus, as described above, is strongly indicative for speciation with gene flow (Crow et al., 2010), as postzygotic isolation would be expected to be higher in case of reinforcement after secondary contact (Coyne \& Orr, 1989, 1997; Berlocher, 1998; Schluter, 1998; Turelli et al., 2001; Via, 2001). Speciation with gene flow seems the most parsimonious explanation in all these taxa. However, data on gene flow is not available, and is required to confirm or reject this hypothesis.

Examining the list of potential cases of marine ecological speciation with gene flow as a whole reveals a phylogenetically diverse group of taxa (fig. 2). However, the taxonomic distribution of potential cases of divergence with gene flow seems to reflect research effort rather than actual occurrence of speciation with gene flow. There are some similarities among the taxa in which ecological speciation with gene flow may have occurred. Many species show differences in either host- or habitat associations or reproductive timing, which may act as a single trait driving divergence when species are philopatric (Servedio et al., 2011). In taxa that do not differ in habitatassociations, some other trait may act as such a 'magic' trait (e.g., body size in seahorses, see Jones et al., 2003; colour pattern in hamlets, see Puebla et al., 2007). As speciation with gene flow is thought to happen most easily in case a single trait is involved in both selection and assortative mating (Maynard Smith, 1966) and such traits are less rare than previously assumed (Servedio et al., 2011), it should be no surprise that such traits are potentially involved in most of the taxa discussed here, even though single traits may not be able to induce perfect assortative mating and decrease gene 
flow to zero in the real world. The Hawaiian limpet species (Cellana spp., Bird et al., 2011), as well as the depth-segregated morphotypes of the broadcast spawning, scleractinian corals Seriatopora hystrix (see Bongaerts et al., 2010) and Montastraea cavernosa (see Serrano et al., 2014) are the only taxa discussed here where a clear single trait that may potentially drive divergence cannot be indicated.

The majority of the cases discussed here involve taxa from tropical regions. Biodiversity in general is much higher in the lower latitudes (e.g., Reaka-Kudla, 1997; Hillebrand, 2004; Hoeksema, 2007) and symbiosis, and therefore the potential for diverging host-associations given the high diversity of potential host species, is very common on tropical reefs (Zann, 1987; Stella et al., 2011; Hoeksema et al., 2012). Many species (e.g., Synalpheus brooksi Coutière, 1909: Duffy, 1996a; Epitoniidae: Gittenberger \& Gittenberger, 2005; Leptoconchus spp.: Gittenberger \& Gittenberger, 2011; Coralliophila caribaea Abbott, 1958: Potkamp et al., 2017; Opecarcinus hypostegus (Shaw \& Hopkins, 1977): Van Tienderen \& Van der Meij, 2017) show some degree of host-associated genetic divergence, similar to several of the species discussed here. Ecological speciation with gene flow may therefore occur relatively more frequently in tropical latitudes.

With the exception of the Atlantic cod Gadus morhua (see Barth et al., 2017), marine pelagic species are absent from the list of case studies. Several studies have reported local adaptation in pelagic species (e.g., the Atlantic herring Clupea harengus Linnaeus, 1758: Limborg et al., 2012; pteropods of the genus Cuvierina Boas, 1886: Burridge et al., 2015; the copepods Acartia tonsa Dana, 1849 and Pleuromamma xiphias (Giesbrecht, 1889): Chen \& Hare, 2011 and Goetze et al., 2017 respectively; the foraminiferan Neogloboquadrina pachyderma (Ehrenberg, 1861): Darling et al., 2007; the diatom Skeletonema marinoi Sarno \& Zingone, 2005: Sjöqvist et al., 2015; bottlenose dolphins of the genus Tursiops Gervais, 1855: Louis et al., 2014; see also Norris, 200o; Johannesson \& André, 2006; Peijnenburg \& Goetze, 2013; Bowen et al., 2016). Evidence for potential (historical) gene flow is, however, absent in these species. Gene flow might, therefore, be restricted for example oceanographic instead of ecological conditions. Local adaptation in pelagic species with high dispersal capabilities, even when populations occur in sympatry, does not necessarily mean that these populations diverged from a sympatric, panmictic population (Foote et al., 2011; Foote \& Morin, 2016). More data on historical gene flow among locally adapted pelagic populations is needed. In G. morhua (see also supplementary table $\mathrm{S} 1$ ), some data on connectivity among populations is available. Barth et al. (2017) concluded that connectivity between locally adapted, genetically diverged Atlantic cod populations was high based on biophysical modelling of larval dynamics, these results might potentially be extrapolated to other species in the same region (e.g., the Atlantic herring $C$. harengus, see Limborg et al., 2012).

Identifying isolated cases of ecological speciation with gene flow, as in the majority of studies discussed here, will not progress towards understanding the frequency of ecological speciation (Coyne, 2007; see also Butlin et al., 2012). Only in a few studies discussed here has speciation been studied in a wider phylogenetic context. The importance of ecological speciation is well-studied in the hamlet genus Hypoplectrus, and is thought to have played a large role in the diversification of the genus (Ramon et al., 2003; Puebla et al., 2007, 2008; Holt et al., 2011; Puebla et al., 2012, 2014; Picq et al., 2016). For example, some potential cases of ecological speciation with gene flow have been identified based on phylogenetic studies of grunts (Rocha et al., 2008; Rocha \& Bowen, 2008; Bernal et al., 2017) and seahorses (Jones et al., 2003), where ecological speciation with gene flow may have been the mechanism gene flow may have been the mechanism 
behind the divergence between some, but not all, pairs of sister species. The patterns from these phylogenetic studies suggest a relatively small role for ecological speciation with gene flow. Similar results were found by Reid et al. (2012) in littorinid gastropods based on phylogeographic patterns. So far, detailed, systematic studies on the importance of marine ecological speciation with gene flow in nonfish taxa are lacking. However, the studies discussed here suggest that ecological speciation with gene flow may be an important driver of divergence in coral reef symbionts (Duffy, 1996b; Munday et al., 2004; Faucci et al., 2007; Tsang et al., 2009; Duchene et al., 2013; Hurt et al., 2013; Fritts-Penniman, 2016; Simmonds, 2016; Simmonds et al., 2018) and depthsegregated populations of corals (Carlon \& Budd, 2002; Bongaerts et al., 2010; Prada \& Hellberg, 2013; Serrano et al., 2014; Costantini et al., 2016; Serrano et al., 2016; Bongaerts et al., 2017). Therefore, systematic assessments of many more, both species-poor and speciesrich, phylogenetically diverse clades are needed to assess the frequency of speciation with gene flow in marine systems (see also Via, 2001; Butlin et al., 2012).

Finally, an important point to consider when discussing ecological speciation with gene flow is that the degree of gene flow may not be constant during the process of speciation. Speciation is often more complex than a simple scenario of speciation either with or without gene flow (Johannesson, 2010). For example, speciation may start in isolation and be completed in the presence of gene flow, for example following secondary contact (i.e., reinforcement; Liou \& Price, 1994; Butlin, 1995; Schluter, 2001; Turelli et al., 2001; OrtizBarrientos et al., 2009; Johannesson, 2010). A combination of different models of speciation will most likely also be applicable to most of the cases discussed here, further complicating any general conclusions that may be drawn from these results.

\section{Directions for future research}

Arguments for speciation with gene flow are lacking on several points. Taking these points into account in future studies will improve the confidence with which speciation with gene flow could be inferred. For example, the presence of single traits driving divergence is based on observational data only, with the exception of shell size in the intertidal gastropod Littorina saxatilis (Rolán-Alvarez et al., 1997; Rolán-Alvarez, 2007; Servedio et al., 2011). These 'magic' traits, both subjected to disruptive selection and resulting in assortative mating, are hypothesized to drive divergence with gene flow in the majority of cases discussed here. Data from manipulative experiments will increase the strength of evidence for a single trait driving divergence.

Data on genetic architecture of adaptive traits may contribute to understanding the genomic mechanism of speciation. Chromosomal rearrangements are, for example, known to play a role in adaptation and potentially speciation (Hoffmann \& Rieseberg, 2008; Schwander et al., 2014; Barth et al., 2017). As discussed above, such chromosomal rearrangements are thought to have played a role in the divergence between Atlantic cod Gadus morhua populations and may allow local adaptation despite ongoing gene flow (Berg et al., 2015, 2016; Kirubakaran et al., 2016; Sodeland et al., 2016; Barth et al., 2017). Similar mechanisms might play a role in the divergence within other species discussed here. Genomic data is however still lacking in many of these non-model species, impeding the detection of such mechanisms.

Distinguishing between the population genetic process and the biogeographic pattern of speciation is important. Terms and objectives should always be defined properly to avoid the confusing of pattern with process (Bird et al., 2012). Mathematical models and statistical, population genomic methods Downloaded from Brill. Come4/26/2023 09:21:23AM 
adopt a population genetic approach, testing the degree of gene flow (i.e., divergence with gene flow) instead of the geographic context of speciation (i.e., sympatric speciation) (Gavrilets, 2003; Fitzpatrick et al., 2008). Many studies discussed here explicitly studied the geography of speciation and found evidence for sympatric speciation (e.g., Munday et al., 2004; Crow et al., 2010; Bird et al., 2011). It seems likely that sympatric speciation in most of these cases is equivalent to ecological speciation with gene flow. However, with data on (historical) gene flow lacking, definitive conclusions cannot be drawn.

The main challenge in inferring speciation with gene flow is the rejection of the alternative hypothesis of speciation without gene flow. The timing of gene flow relative to the divergence is not always considered in studies of speciation (Nosil, 2008), which may lead to incorrect assessments of speciation. To distinguish between divergence with gene flow and secondary contact, Crow et al. (2010) studied patterns of pre- and postzygotic reproductive isolation in Japanese greenlings (Hexagrammos spp.) and, as discussed above, found a pattern indicative of divergence with gene flow instead of reinforcement after secondary contact. This approach might not be generally applicable, as it may not be possible to rear certain species in laboratory environments.

Going forward, standardised, generally applicable methods, which formally test contradictory hypotheses and are able to discriminate between divergence with gene flow and secondary contact, should be used to confidently answer questions on speciation, compare results between taxa, and assess the generality of speciation with gene flow (Nosil, 2008; Johannesson, 2010). ABC may serve as a basis for such a method, even though this approach has its limitations as well, and has been criticised by some authors (e.g., Templeton, 2009, 2010; Robert et al., 2011). Several studies have used ABC to explicitly test phylogeographic models, including divergence with gene flow (e.g., Li et al., 2010; Duvaux et al., 2011; Pettengil \& Moeller, 2012; Chu et al., 2013; Rougemont et al., 2016), also in marine systems (e.g., Hickerson \& Meyer, 2008; Ilves et al., 2010; Boehm et al., 2013; Roux et al., 2013, 2014). Of the studies discussed here, only Butlin et al. (2014) used ABC, to study divergence between ecotypes of the gastropod Littorina saxatilis. Combining statistical methods such as $\mathrm{ABC}$ with genome-wide SNPs from nextgeneration sequencing protocols (Baird et al., 2008; Cornuet et al., 2014; Andrews et al., 2016) provides a powerful set of tools to study speciation in non-model species. Additionally, the development of third generation sequencing, providing fast and easy access to sequencing in the field and generating long reads, will likely provide new methods to study speciation in non-model species and again transform the field of evolutionary biology over the next decade (Bleidorn, 2016).

Based on all studies discussed here, we can state that speciation with gene flow has played a role in the diversification of several marine taxa, and many compelling cases of potential speciation with gene flow are to be found in the marine realm. However, the frequency of ecological speciation with gene flow cannot be assessed with these data. More systematic assessments of a more diverse range of marine taxa are required to understand the factors leading to speciation with gene flow. As speciation occurs at the population-species boundary, focussing analyses at this boundary may be most informative (Losos \& Glor, 2003). Formally testing hypotheses of speciation within a wide range of marine clades (Bird et al., 2012; Butlin et al., 2012), using generally applicable, standardized methods, may bring us closer to answering the question on the importance of speciation with gene flow in marine systems. 


\section{Acknowledgements}

We thank J.A.J. Metz (Leiden University), M. Schilthuizen (Naturalis Biodiversity Center, Leiden University) and an anonymous reviewer for reading an earlier version of the manuscript and providing valuable feedback. We also thank the reviewers K.T.C.A. Peijnenburg (Naturalis Biodiversity Center), K.M. Hultgren (Seattle University) and K. Johannesson (University of Gothenburg) for helpful comments on the manuscript. We also thank Arthur Anker (Federal University of Goiás), P. Larsson and K. Johannesson (University of Gothenburg), Z. Kanamoto (Ehime University) and K.D. Crow (San Francisco State University), A. Fritts-Penniman (California Academy of Sciences), P.L. Munday (James Cook University), Y.W. Lau (University of the Ryukyus), O. Puebla (GEOMAR Helmholtz Centre for Ocean Research), E. Rose (University of Tampa) and A.G. Jones (University of Idaho), S.E. Simmonds (University of California, Los Angeles), and N.J. de Voogd (Naturalis Biodiversity Center) for kindly providing the photos used in fig. 1 .

\section{Supplementary material}

Supplementary material is available online at: https://brill.figshare.com/s/6f8caoa6829 4f7oa8e 53

\section{References}

Abbott, R.T. (1958) Marine mollusks of Grand Cayman Island, British West Indies. Monogr. Acad. Nat. Sci. Philadelphia, 11, 1-138.

Adams, H. (1869) Description of a new genus and fourteen new species of marine shells. Proc. Zool. Soc., 1869, 272-275.

Ahyong, S.T. \& Ng, P.K.L. (2008) Alain raymondi, a new species of deepwater pinnotherid crab
(Crustacea: Decapoda: Brachyura) from the Philippines, commensal with holothurians. Zootaxa, 68, 61-68.

Andrews, K.R., Good, J.M., Miller, M.R., Luikart, G. \& Hohenlohe, P.A. (2016) Harnessing the power of RADseq for ecological and evolutionary genomics. Nat. Rev. Genet., 17, 81-92.

Ayre, D.J. \& Dufty, S. (1994) Evidence for restricted gene flow in the viviparous coral Seriatopora hystrix on Australia's Great Barrier Reef. Evolution, 48, 1183-1201.

Ayre, D.J. \& Hughes, T.P. (200o) Genotypic diversity and gene flow in brooding and spawning corals along the Great Barrier Reef, Australia. Evolution, 54, 1590-1605.

Baird, N.A., Etter, P.D., Atwood, T.S., Currey, M.C., Shiver, A.L., Lewis, Z.A., Selker, E.U., Cresko, W.A. \& Johnson, E.A. (2008) Rapid SNP discovery and genetic mapping using sequenced RAD markers. PLoS One, 3, e3376.

Bancroft, E.N. (1829) On the fish known in Jamaica as the sea-devil. Zool. J., London, 4, 444-457.

Barreto, F.S. \& McCartney, M.A. (2007) Extraordinary AFLP fingerprint similarity despite strong assortative mating between reef color morphospecies. Evolution, 62, 226-233.

Barth, J.M.I., Berg, P.R., Jonsson, P.R., Bonanomi, S., Corell, H., Hemmer-Hansen, J., Jakobsen, K.S., Johannesson, K., Jorde, P.E., Knutsen, H., Moksnes, P.-O., Star, B., Stenseth, N.C., Svedäng, H., Jentoft, S. \& André, C. (2017) Genome architecture enables local adaptation of Atlantic cod despite high connectivity. Mol. Ecol., 26, $445^{2-4466 . ~}$

Beaumont, M.A. (2010) Approximate Bayesian computation in evolution and ecology. Annu. Rev. Ecol. Evol. Syst., 41, 379-406.

Beaumont, M.A. \& Balding, D.J. (2004) Identifying adaptive genetic divergence among populations from genome scans. Mol. Ecol., 13, 969-980.

Beaumont, M.A., Nielsen, R., Robert, C., Hey, J., Gaggiotti, O., Knowles, L., Estoup, A., Panchal, M., Corander, J., Hickerson, M., Sisson, S.A., Fagundes, N., Chikhi, L., Beerli, P., Vitalis, R., 
Cornuet, J.-M., Huelsenbeck, J., Foll, M., Yang, Z., Rousset, F., Balding, D. \& Excoffier, L. (2010) In defence of model-based inference in phylogeography. Mol. Ecol., 19, 436-446.

Beaumont, M.A., Zhang, W. \& Balding, D.J. (2002) Approximate Bayesian computation in population genetics. Genetics, 162, 2025-2035.

Beiring, E.A. \& Lasker, H.R. (2000) Egg production by colonies of a gorgonian coral. Mar. Ecol. Prog. Ser., 196, 169-177.

Berg, P.R., Jentoft, S., Star, B., Ring, K.H., Knutsen, H., Lien, S., Jakobsen, K.S. \& André, C. (2015) Adaptation to low salinity promotes genomic divergence in Atlantic cod (Gadus morhua L.). Genome Biol. Evol., 7, 1644-1663.

Berg, P.R., Star, B., Pampoulie, C., Sodeland, M., Barth, J.M.I., Knutsen, H., Jakobsen, K.S. \& Jentoft, S. (2016) Three chromosomal rearrangements promote genomic divergence between migratory and stationary ecotypes of Atlantic cod. Sci. Rep., 6, 23246.

Bergmans, W. (1978) Taxonomic revision of Recent Australian Nuculidae (Mollusca: Bivalvia) except Ennucula Iredale, 1931. Rec. Aust. Mus., 31, 673-736.

Berlocher, S.H. (1998) Can sympatric speciation via host or habitat shift be proven from phylogenetic and biogeographic evidence? In: D.J. Howard \& S.H. Berlocher (Eds) Endless Forms: Species and Speciation, pp. 99-113. Oxford University Press, Oxford.

Bernal, M.A., Gaither, M.R., Simison, W.B. \& Rocha, L.A. (2017) Introgression and selection shaped the evolutionary history of sympatric sisterspecies of coral reef fishes (genus: Haemulon). Mol. Ecol., 26, 639-652.

Beu, A.G. (1987) Taxonomy of gastropods of the families Ranellidae (= Cymatiidae) and Bursidae. Part 2. Descriptions of 14 new modern IndoWest Pacific species and subspecies, with revisions of related taxa. N. Z. J. Zool., 13, 273-355.

Beu, A.G., Bouchet, P. \& Tröndlé, J. (2012) Tonnoidean gastropods of French Polynesia. Molluscan Res., 32, 61-120.
Bierne, N., Roze, D. \& Welch, J.J. (2013) Pervasive selection or is it...? why are $F_{\mathrm{ST}}$ outliers sometimes so frequent? Mol. Ecol., 22, 2061-2064.

Bierne, N., Welch, J., Loire, E., Bonhomme, F. \& David, P. (2011) The coupling hypothesis: why genome scans may fail to map local adaptation genes. Mol. Ecol., 20, 2044-2072.

Billard, E., Serrão, E., Pearson, G., Destombe, C. \& Valero, M. (2010) Fucus vesiculosus and spiralis species complex: a nested model of local adaptation at the shore level. Mar. Ecol. Prog. Ser., 405, 163-174.

Bird, C.E., Fernandez-Silva, I., Skillings, D.J. \& Toonen, R.J. (2012) Sympatric speciation in the post 'modern synthesis' era of evolutionary biology. Evol. Biol., 39, 158-180.

Bird, C.E., Holland, B.S., Bowen, B.W. \& Toonen, R.J. (2011) Diversification of sympatric broadcastspawning limpets (Cellana spp.) within the Hawaiian archipelago. Mol. Ecol., 20, 2128-2141.

Bleeker, P. (1856) Bijdrage tot de kennis der ichthyologische fauna van het eiland Boeroe. Nat. Tijdschr. Ned. Ind., 11, 383-414.

Bleidorn, C. (2016) Third generation sequencing: technology and its potential impact on evolutionary biodiversity research. Syst. Biodivers., 14, $1-8$.

Boas, J.E.V. (1886) Spolia Atlantica. Bidrag til Pteropodernes. Morfologi og systematik samt til kundskaben om deres geografiske udbredelse. K. danske Vidensk. Selsk. Skr., naturv. mat. Afd., (6) 4(1), 1-231.

Boehm, J.T., Waldman, J., Robinson, J.D. \& Hickerson, M.J. (2015) Population genomics reveals seahorses (Hippocampus erectus) of the Western Mid-Atlantic coast to be residents rather than vagrants. PLoS One, 10, e0116219.

Boehm, J.T., Woodall, L., Teske, P.R., Lourie, S.A., Baldwin, C., Waldman, J. \& Hickerson, M. (2013) Marine dispersal and barriers drive Atlantic seahorse diversification (L. Rocha, ed.). J. Biogeogr., 40, 1839-1849.

Bolaños, J., Rivero, W., Hernández, J., Magán, I., Hernández, G., Cuesta, J.A. \& Felder, D.L. (2005) 
Abbreviated larval development of the pea crab Orthotheres barbatus (Decapoda: Brachyura: Pinnotheridae) described from laboratoryreared material, with notes on larval characters of the Pinnotherinae. J. Crust. Biol., 25, 500-506.

Bolnick, D.I. \& Fitzpatrick, B.M. (2007) Sympatric speciation: models and empirical evidence. Annu. Rev. Ecol. Evol. Syst., 38, 459-487.

Bongaerts, P., Riginos, C., Brunner, R., Englebert, N., Smith, S.R. \& Hoegh-Guldberg, O. (2017) Deep reefs are not universal refuges: Reseeding potential varies among coral species. Sci. Adv., 3, e1602373.

Bongaerts, P., Riginos, C., Ridgway, T., Sampayo, E.M., Van Oppen, M.J.H., Englebert, N., Vermeulen, F. \& Hoegh-Guldberg, O. (2010) Genetic divergence across habitats in the widespread coral Seriatopora hystrix and its associated Symbiodinium. PLoS One, 5, e10871.

Bowen, B.W., Rocha, L.A., Toonen, R.J. \& Karl, S.A. (2013) The origins of tropical marine biodiversity. Trends Ecol. Evol., 28, 359-366.

Bowen, B.W., Gaither, M.R., DiBattista, J.D., Iacchei, M., Andrews, K.R., Grant, W.S., Toonen, R.J. \& Briggs, J.C. (2016) Comparative phylogeography of the ocean planet. Proc. Natl. Acad. Sci. U.S.A., 113, 7962-7969.

Braby, C.E., Rouse, G.W., Johnson, S.B., Jones, W.J. \& Vrijenhoek, R.C. (2007) Bathymetric and temporal variation among Osedax boneworms and associated megafauna on whale-falls in Monterey Bay, California. Deep Sea Res. Part I Oceanogr. Res. Pap., 54, 1773-1791.

Bradbury, I.R., Bowman, S., Borza, T., Snelgrove, P.V., Hutchings, J.A., Berg, P.R., RodríguezEzpeleta, N., Lighten, J., Ruzzante, D.E., Taggart, C. \& Bentzen, P. (2014) Long distance linkage disequilibrium and limited hybridization suggest cryptic speciation in Atlantic cod. PLoS One, 9, e106380.

Brazeau, D.A., Lesser, M.P., Slattery, M. (2013) Genetic structure in the coral, Montastraea cavernosa: assessing genetic differentiation among and within mesophotic reefs (M.V. Matz, ed.). PLoS One, 8, e65845.
Burridge, A.K., Goetze, E., Raes, N., Huisman, J. \& Peijnenburg, K.T.C.A. (2015) Global biogeography and evolution of Cuvierina pteropods. BMC Evol. Biol., 15, 39.

Bush, G.L. (1969) Sympatric host race formation and speciation in frugivorous flies of the genus Rhagoletis (Diptera, Tephritidae). Evolution, 23, 237-251.

Butlin, R.K. (1995) Reinforcement: an idea evolving. Trends Ecol. Evol., 10, 432-434.

Butlin, R.K., Debelle, A., Kerth, C., Snook, R.R., Beukeboom, L.W., Castillo Cajas, R.F., Diao, W., Maan, M.E., Paolucci, S., Weissing, F.J., et al. (2012) What do we need to know about speciation? Trends Ecol. Evol., 27, 27-39.

Butlin, R.K., Galindo, J. \& Grahame, J.W. (2008) Sympatric, parapatric or allopatric: the most important way to classify speciation? Philos. Trans. R. Soc. London, Ser. B, 363, 2997-3007.

Butlin, R.K., Saura, M., Charrier, G., Jackson, B., André, C., Caballero, A., Coyne, J.A., Galindo, J., Grahame, J.W., Hollander, J., et al. (2014) Parallel evolution of local adaptation and reproductive isolation in the face of gene flow. Evolution, 68, 935-949.

Carlon, D.B. \& Budd, A.F. (2002) Incipient speciation across a depth gradient in a scleractinian coral? Evolution, 56, 2227-2242.

Carlon, D.B. \& Lippé, C. (2011) Estimation of mating systems in Short and Tall ecomorphs of the coral Favia fragum. Mol. Ecol., 20, 812-828.

Carlon, D.B. \& Olson, R.R. (1993). Larval dispersal distance as an explanation for adult spatial pattern in two Caribbean reef corals. J. Exp. Mar. Biol. Ecol., 173, 247-263.

Carlon, D.B., Budd, A.F., Lippé, C. \& Andrew, R.L. (2011). The quantitative genetics of incipient speciation: heritability and genetic correlations of skeletal traits in populations of diverging $\mathrm{Fa}$ via fragum. Evolution, 65, 3428-3447.

Castelin, M., Lorion, J., Brisset, J., Cruaud, C., Maestrati, P., Utge, J. \& Samadi, S. (2012) Speciation patterns in gastropods with long-lived larvae from deep-sea seamounts. Mol. Ecol., 21, 4828-4853. 
Cavalier-Smith, T. (2018) Kingdom Chromista and its eight phyla: a new synthesis emphasising periplastid protein targeting, cytoskeletal and periplastid evolution, and ancient divergences. Protoplasma, 255, 297-357.

Chase, M.R., Etter, R.J., Rex, M.A. \& Quattro, J.M. (1998) Bathymetric patterns of genetic variation in a deep-sea protobranch bivalve, Deminucula atacellana. Mar. Biol., 131, 301-308.

Chen, G. \& Hare, M.P. (2011) Cryptic diversity and comparative phylogeography of the estuarine copepod Acartia tonsa on the US Atlantic coast. Mol. Ecol., 20, 2425-2441.

Chu, J.-H., Wegmann, D., Yeh, C.-F., Lin, R.-C., Yang, X.-J., Lei, F.-M., Yao, C.-T., Zou, F.-S. \& Li, S.-H. (2013) Inferring the geographic mode of speciation by contrasting autosomal and sex-linked genetic diversity. Mol. Biol. Evol., 30, 2519-2530.

Clarke, F.E. (1879) On some new fishes. Trans. Proc. N. Z. Inst., 11 [for 1878], 291-295.

Cornuet, J.-M., Pudlo, P., Veyssier, J., Dehne-Garcia, A., Gautier, M., Leblois, R., Marin, J.-M. \& Estoup, A. (2014) DIYABC v2.0: a software to make approximate Bayesian computation inferences about population history using single nucleotide polymorphism, DNA sequence and microsatellite data. Bioinformatics, 30, 1187-1189.

Corrigan, S. \& Beheregaray, L.B. (2009) A recent shark radiation: molecular phylogeny, biogeography and speciation of wobbegong sharks (family: Orectolobidae). Mol. Phylogenet. Evol., 52, 205-216.

Corrigan, S., Huveneers, C., Schwartz, T.S., Harcourt, R.G. \& Beheregaray, L.B. (2008). Genetic and reproductive evidence for two species of ornate wobbegong shark Orectolobus spp. on the Australian east coast. J. Fish Biol., 73, 1662-1675.

Costantini, F., Gori, A., Lopez-González, P., Bramanti, L., Rossi, S., Gili, J.-M. \& Abbiati, M. (2016) Limited genetic connectivity between gorgonian morphotypes along a depth gradient. PLoS One, 11, e0160678.

Coutière, H. (1909). The American species of snapping shrimps of the genus Synalpheus. Proc. $U$. S. Nat. Mus., 36, 1-93.
Coyer, J.A., Hoarau, G., Costa, J.F., Hogerdijk, B., Serrão, E.A., Billard, E., Valero, M., Pearson, G.A. \& Olsen, J.L. (2011). Evolution and diversification within the intertidal brown macroalgae Fucus spiralis/F. vesiculosus species complex in the North Atlantic. Mol. Phylogenet. Evol., 58, $283-296$.

Coyne, J.A. (2007) Sympatric speciation. Curr. Biol., ${ }_{17}, \mathrm{R}_{7} 87-\mathrm{R}_{7} 88$.

Coyne, J.A. \& Orr, H.A. (1989) Patterns of speciation in Drosophila. Evolution, 43, 362-381.

Coyne, J.A. \& Orr, H.A. (1997) 'Patterns of speciation in Drosophila' revisited. Evolution, 51, 295-303.

Coyne, J.A. \& Orr, H.A. 2004. Speciation. Sinauer Associates, Sunderland, Massachusetts.

Crow, K.D., Munehara, H. \& Bernardi, G. (2010) Sympatric speciation in a genus of marine reef fishes. Mol. Ecol., 19, 2089-2105.

Crow, K.D., Munehara, H., Kanamoto, Z., Balanov, A., Antonenko, D. \& Bernardi, G. (2007) Maintenance of species boundaries despite rampant hybridization between three species of reef fishes (Hexagrammidae): implications for the role of selection. Biol. J. Linn. Soc., 91, 135-147.

Cruaud, A. \& Rasplus, J.Y. (2016) Testing cospeciation through large-scale cophylogenetic studies. Curr. Opin. Insect Sci., 18, 53-59.

Csilléry, K., Blum, M.G.B., Gaggiotti, O.E. \& François, O. (2010) Approximate Bayesian computation (ABC) in practice. Trends Ecol. Evol., 25, $410-418$.

Cuvier, G. \& Valenciennes, A. (1828). Histoire naturelle des poissons. Tome second. Livre Troisième. Des poissons de la famille des perches, ou des percoïdes 2 : $\mathrm{i}-\mathrm{xxi}+2$ pp. $+1-490$. [Valenciennes author of pp. 238-249, 262-386, Cuvier the remainder. $\mathrm{i}-\mathrm{xvii}+{ }^{1-317}$ in Strasbourg edition.]

Cuvier, G. \& Valenciennes, A. (1830). Histoire naturelle des poissons. Tome cinquième. Livre cinquième. Des Sciénoïdes 5: i-xxviii + 1-499 + 4 pp. [Cuvier authored volume. $\mathrm{i}-\mathrm{xx}+1-374$ in Strasbourg edition.] 
Dana, J.D. (1846-1849) Zoophytes. United States Exploring Expedition during the years 1838-1842. Lea and Blanchard, Philadelphia. 7: 1-740, 61 pls. [1846: 1-120, 709-720; 1848: 121-708, 721-740; 1849: atlas pls. 1-61].

Dana, J.D. (1849) Conspectus crustaceorum, quae in orbis terrarum circumnavigatione, Carolo Wilkes, e classe Reipublicae foederatae duce, lexit et descripsit Jacobus D. Dana. Am. J. Sci., $8,276-285$.

Darling, K.F., Kucera, M. \& Wade, C.M. (2007). Global molecular phylogeography reveals persistent Arctic circumpolar isolation in a marine planktonic protist. Proc. Natl. Acad. Sci. U.S.A., 104: 5002-5007.

Darwin, C. (1854). A Monograph on the Sub-Class Cirripedia with Figures of all Species. Vol. 2: The Balanidae, The Verrucidae. Ray Society, London.

Darwin, C. (1859) On the Origin of Species by Means of Natural Selection, or the Preservation of Favoured Races in the Struggle for Life. John Murray, Albemarle Street, London.

Daudin, F.M. (1803) Histoire naturelle, générale et particulière des reptiles. Dufart, Paris.

Dawson, M.N., Louie, K.D., Barlow, M., Jacobs, D.K. \& Swift, C.C. (2002). Comparative phylogeography of sympatric sister species, Clevelandia ios and Eucyclogobius newberryi (Teleostei, Gobiidae), across the California Transition Zone. Mol. Ecol., 11, 1065-1075.

Dawson, M.N., Staton, J.L. \& Jacobs, D.K. (2001). Phylogeography of the tidewater goby, Eucyclogobius newberryi (Teleostei, Gobiidae), in coastal California. Evolution, 55, 1167-1179.

Demond, J. (1957) Micronesian reef-associated gastropods. Pac. Sci., 11, 275-341.

Dickinson, H. \& Antonovics, J. (1973). Theoretical considerations of sympatric divergence. Am. Nat., 107, 256-274.

Dieckmann, U. \& Doebeli, M. (1999) On the origin of species by sympatric speciation. Nature, 400, 354-357.

Dobkin, S. (1969) Abbreviated larval development in caridean shrimps and its significance in the artificial culture of these animals. FAO Fish. Rep., 3, 935-946.

Dobkin, S.R. (1965) The first post-embryonic stage of Synalpheus brooksi Coutiere. Bull. Mar. Sci., $15,450-462$.

Doebeli, M. \& Dieckmann, U. (2000) Evolutionary branching and sympatric speciation caused by different types of ecological interactions. Am. Nat., 156, S77-S101.

Doellman, M.M., Trussell, G.C., Grahame, J.W. \& Vollmer, S.V. (2011). Phylogeographic analysis reveals a deep lineage split within North Atlantic Littorina saxatilis. Proc. R. Soc. London, Ser. B, $278,3175-3183$.

Drès, M. \& Mallet, J. (2002) Host races in plantfeeding insects and their importance in sympatric speciation. Philos. Trans. R. Soc. London, Ser. B, 357, 471-492.

Duchene, D., Klanten, S.O., Munday, P.L., Herler, J. \& van Herwerden, L. (2013) Phylogenetic evidence for recent diversification of obligate coral-dwelling gobies compared with their host corals. Mol. Phylogenet. Evol., 69, 123-132.

Duffy, J.E. (1996a). Resource-associated population subdivision in a symbiotic coral-reef shrimp. Evolution, 50, 360-373.

Duffy, J.E. (1996b) Species boundaries, specialization, and the radiation of sponge-dwelling alpheid shrimp. Biol. J. Linn. Soc., 58, 307-324.

Dunn, C.W., Giribet, G., Edgecombe, G.D. \& Hejnol, A. (2014) Animal phylogeny and its evolutionary implications. Annu. Rev. Ecol. Evol. Syst., 45, 371-395.

Duran, S. \& Rützler, K. (2006). Ecological speciation in a Caribbean marine sponge. Mol. Phylogenet. Evol., 40, 292-297.

Duvaux, L., Belkhir, K., Boulesteix, M. \& Boursot, P. (2011) Isolation and gene flow: inferring the speciation history of European house mice. Mol. Ecol., 20, 5248-5264.

Earl, D.A., Louie, K.D., Bardeleben, C., Swift, C.C. \& Jacobs, D.K. (2010) Rangewide microsatellite phylogeography of the endangered tidewater goby, Eucyclogobius newberryi (Teleostei: Gobiidae), a genetically subdivided coastal fish Downloaded from Brill.com04/26/2023 09:21:23AM 
with limited marine dispersal. Conserv. Genet., 11, 103-114.

Ehrenberg, C.G. (1861) Elemente des tiefen Meeresgrundes in Mexikanischen Golfstrome bei Florida: Ober die Tiefgrund-Verhaltnisse des Oceans am Eingange der Davisstrasse und bei Island. Monatsber. Akad. Berlin, 1961, 222-240, 275-315.

Esper, E.J.C. (1791) Die Pflanzenthiere in Abbildungen nach der Natur. Achte Lieferung. Raspischen Buchhandlung, Nürnberg. [For dates of publication, see Ott, 1995].

Esper, E.J.C. (1793) Die Pflanzenthiere in Abbildungen nach der Natur. Eilfte Lieferung. Raspischen Buchhandlung, Nürnberg. [For dates of publication, see Ott, 1995].

Faucci, A., Toonen, R.J. \& Hadfield, M.G. (2007) Host shift and speciation in a coral-feeding nudibranch. Proc. R. Soc. London, Ser. B, 274, 111-119.

Feary, D.A. \& Clements, K.D. (2006) Habitat use by triplefin species (Tripterygiidae) on rocky reefs in New Zealand. J. Fish Biol., 69, 1031-1046.

Feder, J.L., Chilcote, C.A. \& Bush, G.L. (1988) Genetic differentiation between sympatric host races of the apple maggot fly Rhagoletis pomonella. Nature, 336, 61-64.

Feder, J.L., Flaxman, S.M., Egan, S.P., Comeault, A.A. \& Nosil, P. (2013) Geographic mode of speciation and genomic divergence. Annu. Rev. Ecol. Evol. Syst., 44, 73-97.

Fedrizzi, N., Stiassny, M.L.J., Boehm, J.T., Dougherty, E.R., Amato, G. \& Mendez, M. (2015) Population genetic structure of the dwarf seahorse (Hippocampus zosterae) in Florida. PLoS One, 10, e0132308.

Felsenstein, J. (1981). Skepticism towards Santa Rosalia, or why are there so few kinds of animals? Evolution, 35, 124-138.

Filhol, H. (1885) Considérations relatives à la Faune des Crustacés de la Nouvelle-Zélande. Biblioth. Éc. Ht. Étud., Sect. Sci. Nat., 30, 1-6o.

Fischer, E.A. (1980) Speciation in the hamlets (Hypoplectrus: Serranidae): a continuing enigma. Copeia, 1980, 649-659.
Fisher, R., O'Leary, R.A., Low-Choy, S., Mengersen, K., Knowlton, N., Brainard, R.E. \& Caley, M.J. (2015) Species richness on coral reefs and the pursuit of convergent global estimates. Curr. Biol., 25, 500-505.

Fitzpatrick, B.M., Fordyce, J.A. \& Gavrilets, S. (2008) What, if anything, is sympatric speciation? J. Evol. Biol., 21, 1452-1459.

Fitzpatrick, B.M., Fordyce, J.A. \& Gavrilets, S. (2009). Pattern, process and geographic modes of speciation. J. Evol. Biol., 22, 2342-2347.

Foote, A.D. \& Morin, P.A. (2016) Genome-wide SNP data suggest complex ancestry of sympatric North Pacific killer whale ecotypes. Heredity, 117, 316-325.

Foote, A.D., Morin, P.A., Durban, J.W., Willerslev, E., Orlando, L. \& Gilbert, M.T.P. (2011) Out of the Pacific and back again: insights into the matrilineal history of Pacific killer whale ecotypes. PLoS One, 6, e24980.

Forbes, A.A., Devine, S.N., Hippee, A.C., Tvedte, E.S., Ward, A.K.G., Widmayer, H.A. \& Wilson, C.J. (2017) Revisiting the particular role of host shifts in initiating insect speciation. Evolution, 71, 1126-1137.

Fourcade, Y., Chaput-Bardy, A., Secondi, J., Fleurant, C. \& Lemaire, C. (2013) Is local selection so widespread in river organisms? Fractal geometry of river networks leads to high bias in outlier detection. Mol. Ecol., 22, 2065-2073.

Fritts-Penniman, A.L. (2016) Ecological speciation and cryptic diversity of coral-associated nudibranchs. PhD Thesis. University of California, Los Angeles.

Fujioka, Y. \& Yamazato, K. (1983) Host selection of some Okinawan coral associated gastropods belonging to the genera Drupella, Coralliophila and Quoyula. Galaxea, 2, 59-73.

Funk, D.J. \& Omland, K.E. (2003) Species-level paraphyly and polyphyly: frequency, causes, and consequences, with insights from animal mitochondrial DNA. Annu. Rev. Ecol. Evol. Syst., 34, 397-423.

Gaggiotti, O.E. (2011) Making inferences about speciation using sophisticated statistical genetics Downloaded from Brill.com04/26/2023 09:21:23AM 
methods: look before you leap. Mol. Ecol., 20, 2229-2232.

García-Machado, E., Chevalier Monteagudo, P.P. \& Solignac, M. (2004) Lack of mtDNA differentiation among hamlets (Hypoplectrus, Serranidae). Mar. Biol., 144, 147-152.

Gavrilets, S. (2003). Perspective: Models of speciation: what have we learned in 40 years. Evolution, 57, 2197-2215.

Gavrilets, S. (2004) Fitness Landscapes and the Origin of Species. Princeton University Press, Princeton, NJ.

Gavrilets, S. (2006) The Maynard Smith model of sympatric speciation. J. Theor. Biol., 239, 172-182.

Gervais, P.(1855) Histoire naturelle des mammifères: avec l'indication de leurs moeurs, et de leurs rapports avec les arts, le commerce et l'agriculture. L. Curmer, Paris. Vol. 2, (Hist. Nat. Mammifères) Edition, 1-344.

Giesbrecht, W. (1889) Elenco dei Copepodi pelagici raccolti dal tenente di vascello Gaetano Chierchia durante il viaggio della R. Corvetta "Vettor Pisani" negli anni 1882-1885 e del di vascello Francesco Orsini nel Mar Rosso, nel 1884. Atti Acad. naz. Lincei Rc., (4)5(2), 24-29.

Gill, T.N. (1861) Two new species of marine fishes. Proc. Acad. Nat. Sci. Philadelphia, 13, 98-99.

Gill, T.N. (1862) Catalogue of the fishes of Lower California, in the Smithsonian Institution, collected by Mr. J. Xantus Part III. Proc. Acad. Nat. Sci. Philadelphia, 14, 249-262.

Girard, C. (1856) Contributions to the ichthyology of the western coast of the United States from specimens in the museum of the Smithsonian Institution. Proc. Acad. Nat. Sci. Philadelphia, 8(3), 131-137.

Gittenberger, A. \& Gittenberger, E. (2005) A hitherto unnoticed adaptive radiation: epitoniid species (Gastropoda : Epitoniidae) associated with corals (Scleractinia). Contrib. Zool., 74, 125-203.

Gittenberger, A. \& Gittenberger, E. (2011) Cryptic, adaptive radiation of endoparasitic snails: sibling species of Leptoconchus (Gastropoda:
Coralliophilidae) in corals. Org. Divers. Evol., 11, 21-41.

Goetze, E.G., Hüdepohl, P.T., Chang, C., Van Woudenberg, L., Iacchei, M. \& Peijnenburg K.T.C.A. (2017). Ecological dispersal barrier across the equatorial Atlantic in a migratory planktonic copepod. Prog. Oceanogr. (special AMT issue), 158, 203-212.

Goodbody-Gringley, G., Marchini, C., Chequer, A.D \& Goffredo, S. (2015) Population structure of Montastraea cavernosa on shallow versus mesophotic reefs in Bermuda (C.A. Chen, ed.). PLoS One, 10, e0142427.

Goodbody-Gringley, G., Vollmer, S.V., Woollacott, R.M. \& Giribet, G. (2010) Limited gene flow in the brooding coral Favia fragum (Esper, 1797). Mar. Biol., 157, 2591-2602.

Goodbody-Gringley, G., Woollacott, R.M. \& Giribet, G. (2012) Population structure and connectivity in the Atlantic scleractinian coral Montastraea cavernosa (Linnaeus, 1767). Mar. Ecol., 33, $3^{2-48 .}$

Goodbody, I. (1960) Abbreviated development in a pinnotherid crab. Nature, 185, 704-705.

Gray, J.E. (1849) Catalogue of the Specimens of Snakes in the Collection of the British Museum. Edward Newman, London.

Hardy, G.M. (1986) Redescription of Gilloblennius Whitley and Phillipps, 1939 (Pisces: Tripterygiidae), and description of a new genus and two new species from New Zealand.J. Roy. Soc. N. Z., 16, 145-168.

Hellberg, M.E. (1998) Sympatric sea shells along the sea's shore: the geography of speciation in the marine gastropod Tegula. Evolution, 52, 1311-1324.

Hey, J. (2006) Recent advances in assessing gene flow between diverging populations and species. Curr. Opin. Genet. Dev., 16, 592-596.

Hey, J. \& Nielsen, R. (2004) Multilocus methods for estimating population sizes, migration rates and divergence time, with applications to the divergence of Drosophila pseudoobscura and $D$. persimilis. Genetics, $167,747-760$. 
Hickerson, M.J. \& Meyer, C.P. (2008) Testing comparative phylogeographic models of marine vicariance and dispersal using a hierarchical Bayesian approach. BMC Evol. Biol., 8, 322.

Hickerson, M.J., Dolman, G. \& Mortiz, C. (2006) Comparative phylogeographic summary statistics for testing simultaneous vicariance. Mol. Ecol., 15, 209-223.

Hickey, A.J.R., Lavery, S.D., Hannan, D.A., Baker, C. \& Clements, K.D. (2009) New Zealand triplefin fishes (family Tripterygiidae): contrasting population structure and mtDNA diversity within a marine species flock. Mol. Ecol., 18, 680-696.

Hillebrand, H. (2004) On the generality of the latitudinal diversity gradient. Am. Nat., 163, 192-211.

Hoeksema, B.W. (2007) Delineation of the IndoMalayan centre of maximum marine biodiversity: the coral triangle. In: W. Renema (Ed.) Biogeography, Time, and Place: Distributions, Barriers, and Islands, pp. 117-178. Springer Netherlands, Dordrecht.

Hoeksema, B.W., Van der Meij, S.E.T. \& Fransen, C.H.J.M. (2012) The mushroom coral as a habitat.J. Mar. Biol. Assoc. U. K., 92, 647-663.

Hoffmann, A.A. \& Rieseberg, L.H. (2008) Revisiting the impact of inversions in evolution: from population genetic markers to drivers of adaptive shifts and speciation? Annu. Rev. Ecol. Evol. Syst., 39, 21-42.

Hollander, J., Galindo, J. \& Butlin, R.K. (2015) Selection on outlier loci and their association with adaptive phenotypes in Littorina saxatilis contact zones.J. Evol. Biol., 28, 328-337.

Hollander, J., Lindegarth, M. \& Johannesson, K. (2005) Local adaptation but not geographical separation promotes assortative mating in a snail. Anim. Behav., 70, 1209-1219.

Holt, B.G., Côté, I.M. \& Emerson, B.C. (2011) Searching for speciation genes: molecular evidence for selection associated with colour morphotypes in the Caribbean reef fish genus Hypoplectrus. PLoS One, 6, e20394.

Howell, K.L., Rogers, A.D., Tyler, P.A. \& Billett, D.S.M. (2004) Reproductive isolation among morphotypes of the Atlantic seastar species Zoroaster fulgens (Asteroidea: Echinodermata). Mar. Biol., 144, 977-984.

Hull, S.L., Grahame, J. \& Mill, P.J. (1996) Morphological divergence and evidence for reproductive isolation in Littorina saxatilis (Olivi) in Northeast England.J. Molluscan Stud., 62, 89-99.

Hurt, C., Silliman, K., Anker, A. \& Knowlton, N. (2013) Ecological speciation in anemoneassociated snapping shrimps (Alpheus armatus species complex). Mol. Ecol., 22, 4532-4548.

Ilves, K.L., Huang, W., Wares, J.P. \& Hickerson, M.J. (2010) Colonization and/or mitochondrial selective sweeps across the North Atlantic intertidal assemblage revealed by multi-taxa approximate Bayesian computation. Mol. Ecol., 19, 4505-4519.

Janson, K. (1983) Selection and migration in two distinct phenotypes of Littorina saxatilis in Sweden. Oecologia, 59, 58-61.

Jennings, R.M. \& Etter, R.J. (2014) Phylogeographic estimates of colonization of the deep Atlantic by the protobranch bivalve Nucula atacellana. Pol. Polar Res., 35, 203-224.

Jennings, R.M., Etter, R.J. \& Ficarra, L. (2013) Population differentiation and species formation in the deep sea: the potential role of environmental gradients and depth. PLoS One, 8, 1-19.

Johannesson, B. (1986) Shell morphology of Littorina saxatilis Olivi: the relative importance of physical factors and predation. J. Exp. Mar. Biol. Ecol., 102, 183-195.

Johannesson, K. (2010) Are we analyzing speciation without prejudice? Ann. N.Y. Acad. Sci., 1206, 143-149.

Johannesson, K. \& André, C. (2006) Life on the margin: genetic isolation and diversity loss in a peripheral marine ecosystem, the Baltic Sea. Mol. Ecol., 15, 2013-2029.

Johannesson, K., Havenhand, J.N., Jonsson, P.R., Lindegarth, M., Sundin, A. \& Hollander, J. (2008) Male discrimination of female mucous trails permits assortative mating in a marine snail species. Evolution, 62, 3178-3184. 
Johannesson, K., Panova, M., Kemppainen, P., André, C., Rolán-Alvarez, E. \& Butlin, R.K. (2010) Repeated evolution of reproductive isolation in a marine snail: unveiling mechanisms of speciation. Philos. Trans. R. Soc. London, Ser. B, 365 , 1735-1747.

Johannesson, K., Rolán-Alvarez, E. \& Ekendahl, A. (1995) Incipient reproductive isolation between two sympatric morphs of the intertidal snail Littorina saxatilis. Evolution, 49, 1180-119o.

Johnson, P.A., Hoppensteadt, F.C., Smith, J.J. \& Bush, G.L. (1996) Conditions for sympatric speciation: a diploid model incorporating habitat fidelity and non-habitat assortative mating. Evol. Ecol., 10, 187-205.

Jones, A.G., Moore, G.I., Kvarnemo, C., Walker, D. \& Avise, J.C. (2003) Sympatric speciation as a consequence of male pregnancy in seahorses. Proc. Natl. Acad. Sci. U.S.A., 100, 6598-6603.

Jordan, D.S. \& Gilbert, C.H. (1882) Description of a new species of goby (Gobiosoma ios) from Vancouver's Island. Proc. U. S. Nat. Mus., 5(298), 437-438.

Jordan, D.S. \& Starks, E.C. (1895) The fishes of Puget Sound. Proc. Calif. Acad. Sci., 5, 785-855.

Kashiwagi, T., Marshall, A.D., Bennett, M.B. \& Ovenden, J.R. (2011) Habitat segregation and mosaic sympatry of the two species of manta ray in the Indian and Pacific Oceans: Manta alfredi and M. birostris. Mar. Biodivers. Rec., 4, e53.

Kashiwagi, T., Marshall, A.D., Bennett, M.B. \& Ovenden, J.R. (2012) The genetic signature of recent speciation in manta rays (Manta alfredi and M. birostris). Mol. Phylogenet. Evol., 64, 212-218.

Kawecki, T.J. (1996) Sympatric speciation driven by beneficial mutations. Proc. R. Soc. London, Ser. $B, 263,15^{15}-15^{20}$.

Kawecki, T.J. (1997) Sympatric speciation via habitat specialization driven by deleterious mutations. Evolution, 51, 1751-1763.

Kharin, V.E. (2004) Review of sea snakes of the genus Hydrophis sensu stricto (Serpentes: Hydrophiidae). Russ. J. Mar. Biol., 3o(6), 387-394.
Kiener, L.C. (1835-1837) Spécies général et iconographie des coquilles vivantes. Vol. 8. Famille des Purpurifères. Premièrepartie.Genres Cassidaire, (Cassidaria),Lamarck,pp.1-10, pl.1-2 [all(1835)]; Casque (Cassis), Bruguière, pp. 1-40, pl. 1-16 [all (1835)]; Tonne (Dolium), Lamarck, pp. 1-16, pl. 1-5 [all (1835)]; Harpe (Harpa), Lamarck, pp. 1-12, pl. 1-6 [all (1835)]; Pourpre (Purpura), Lamarck, pp.1-151, pl.1-46 [pp.1-32 (1835),33-8o (1836), 81-151 (1837); pl. 1-21 (1835), 22-39 (1836), 40-46 (1837)]. Rousseau \& J.B. Baillière, Paris.

Kim, E., Lasker, H.R., Coffroth, M.A. \& Kim, K. (2004) Morphological and genetic variation across reef habitats in a broadcast-spawning gorgonian coral. Hydrobiologia, 530/531, 423432.

Kimura, M.R. \& Munehara, H. (2010) The disruption of habitat isolation among three Hexagrammos species by artificial habitat alterations that create mosaic-habitat. Ecol. Res., 25, 41-50.

Kinlan, B.P. \& Gaines, S.D. (2003) Propagule dispersal in marine and terrestrial environments: a community perspective.Ecology, 84, 2007-2020.

Kirubakaran, T.G., Grove, H., Kent, M.P., Sandve, S.R., Baranski, M., Nome, T., De Rosa, M.C., Righino, B., Johansen, T., Otterå, H., Sonesson, A., Lien, S. \& Andersen, Ø. (2016) Two adjacent inversions maintain genomic differentiation between migratory and stationary ecotypes of Atlantic cod. Mol. Ecol., 10, 2130-2143.

Kirkpatrick, M. \& Ravigné, V. (2002) Speciation by natural and sexual selection: models and experiments. Am. Nat., 159, S22-S35.

Knowlton, N. \& Keller, B.D. (1983) A new, sibling species of the snapping shrimp associated with the Caribbean sea anemone Bartholomea annulata. Bull. Mar. Sci., 33, 353-362.

Knowlton, N. \& Keller, B. (1985) Two more sibling species of alpheid shrimps associated with the Caribbean sea anemones Bartholomea annulata and Heteractis lucida. Bull. Mar. Sci., 37, 893-904.

Knowlton, N. \& Keller, B.D. (1986) Larvae which fall far short of their potential: highly localized 
recruitment in an alpheid shrimp with extended larval development. Bull. Mar. Sci., 39, $213-223$.

Kondrashov, A.S. \& Kondrashov, F.A. (1999) Interactions among quantitative traits in the course of sympatric speciation. Nature, 400, 351-354.

Krefft, J.L.G. (1868) Deratoptera alfredi (Prince Alfred's ray). The Illustrated Sydney News, 5 (11 July 1868), 3, 9 .

Krug, P.J. (2011) Patterns of speciation in marine gastropods: a review of the phylogenetic evidence for localized radiations in the sea. Am. Mal. Bull., 29, 169-186.

Ladah, L.B., Feddersen, F., Pearson, G.A. \& Serrão, E.A. (2008) Egg release and settlement patterns of dioecious and hermaphroditic fucoid algae during the tidal cycle. Mar. Biol., 155, 583-591.

Lamouroux, J.V.F. (1821) Exposition méthodique des genres de l'ordre des polypiers, avec leur description et celles des principales espèces, figurées dans 84 planches; les 63 premières appartenant à l'historie naturelle des zoophytes d'Ellis et Solander, pp. 72-76. Mme Veuve Agasse, Paris.

Last, P.R. \& Chidlow, J.A. (2008) Two new wobbegong sharks, Orectolobus floridus sp. nov. and O. parvimaculatus sp. nov. (Orectolobiformes: Orectolobidae), from southwestern Australia. Zootaxa, 67, 49-67.

Lesson, R.P. (1827) Espèce nouvelle d'Hippocampe. Bulletin des Sciences Naturelles et de Géologie (Férussac), Paris, 11, 127-128.

Levene, H. (1953) Genetic equilibrium when more than one ecological niche is available. Am. Nat., $87,331-333$.

Lewontin, R.C. \& Krakauer, J. (1973) Distribution of gene frequency as a test of the theory of the selective neutrality of polymorphisms. Genetics, 74, $175^{-195}$.

Li, J.-W., Yeung, C.K.L., Tsai, P.-W., Lin, R.-C., Yeh, C.F., Yao, C.-T., Han, L., Hung, L.M., Ding, P., Wang, Q., et al. (2010) Rejecting strictly allopatric speciation on a continental island: prolonged postdivergence gene flow between Taiwan (Leucodioptron taewanus, Passeriformes Timaliidae) and Chinese (L. canorum canorum) hwameis. Mol. Ecol., 19, 494-507.

Liou, L.W. \& Price, T.D. (1994) Speciation by reinforcement of premating isolation. Evolution, 48, 1451-1459.

Limborg, M.T., Helyar, S.J., De Bruyn, M., Taylor, M.I., Nielsen, E.E., Ogden, R., Carvalho, G.R., FTP Consortium, Bekkevold, D. (2012) Environmental selection on transcriptome-derived SNPs in a high gene flow marine fish, the Atlantic herring (Clupea harengus). Mol. Ecol., 21, 3686-3703.

Lin, T.-Y. \& Liu, L.-L. (2008) Low levels of genetic differentiation among populations of the coralinhabiting snail Coralliophila violacea (Gastropoda: Coralliophilidea) in regions of the Kuroshio and South China Sea. Zool. Stud., 47, 17-24.

Linnaeus, C. (1753) Species plantarum, exhibentes plantas rite cognitas ad genera relatas cum differentiis specificis, nominibus trivialibus, synonymis selectis, locis natalibus, secundum systema sexuale digestas. Stockholm.

Linnaeus, C. (1758) Systema Naturae per regna tria naturae, secundum classes, ordines, genera, species, cum characteribus, differentiis, synonymis, locis. Editio decima, reformata, pp. i-ii + 1-824. Laurentius Salvius, Holmiae.

Linnaeus, C. (1767) Systema naturae per regna tria naturae: secundum classes, ordines, genera, species, cum characteribus, differentiis, synonymis, locis. Ed. 12. 1., Regnum Animale. 1 \& 2. Laurentii Salvii, Holmiae.

Lohr, K.E., Camp, E.F. \& Manfrino, C. (2014) First record of the basslet Gramma dejongi outside of Cuba. Coral Reefs, 33, 221.

Losos, J.B. \& Glor, R.E. (2003) Phylogenetic comparative methods and the geography of speciation. Trends Ecol. Evol., 18, 220-227.

Lotterhos, K.E. \& Whitlock, M.C. (2014) Evaluation of demographic history and neutral parameterization on the performance of $F_{\mathrm{ST}}$ outlier tests. Mol. Ecol., 23, 2178-2192.

Louis, M., Fontaine, M.C., Spitz, J., Schlund, E., Dabin, W., Deaville, R., Caurant, F., Cherel, Y., 
Guinet, C. \& Simon-Bouhet, B. (2014) Ecological opportunities and specializations shaped genetic divergence in a highly mobile marine top predator. Proc. R. Soc. London, Ser. B, 281, $2014155^{8}$.

Lourie, S.A., Pollom, R.A. \& Foster, S.J. (2016) A global revision of the seahorses Hippocampus Rafinesque 1810 (Actinopterygii: Syngnathiformes): taxonomy and biogeography with recommendations for further research. Zootaxa, $4146,1-66$.

Maas, D.L., Prost, S., Bi, K., Smith, L.L., Armstrong, E.E., Aji, L.P., Toha, A.H.A., Gillespie, R.G. \& Becking, L.E. (2018) Rapid divergence of mussel populations despite incomplete barriers to dispersal. Mol. Ecol., 27, 1556-1571.

Maier, E., Tollrian, R., Rinkevich, B. \& Nürnberger, B. (2005) Isolation by distance in the scleractinian coral Seriatopora hystrix from the Red Sea. Mar. Biol., 147, 1109-1120.

Mallet, J. (2008) Hybridization, ecological races and the nature of species: empirical evidence for the ease of speciation. Philos. Trans. R. Soc. London, Ser. B, 363, 2971-2986.

Mallet, J., Meyer, A., Nosil, P. \& Feder, J.L. (2009) Space, sympatry and speciation.J. Evol. Biol., 22, 2332-2341.

Mateo, J. (2010) Self-referent phenotype matching and long-term maintenance of kin recognition. Anim. Behav., 8o, 929-935.

Marshall, A.D., Compagno, L.J.V. \& Bennett, M.B. (2009) Redescription of the genus Manta with resurrection of Manta alfredi (Krefft, 1868) (Chondrichthyes; Myliobatoidei; Mobulidae). Zootaxa, 2301, 1-28.

Matsubayashi, K.W., Ohshima, I. \& Nosil, P. (2010) Ecological speciation in phytophagous insects. Entomol. Exp. Appl., 134, 1-27.

Maynard Smith, J. (1966) Sympatric speciation. Am. Nat., 100, 637-650.

Mayr, E. (1942) Systematics and the Origin of Species, from the Viewpoint of a Zoologist. Columbia University Press, New York.

Mayr, E. (1954) Geographic speciation in tropical echinoids. Evolution, 8, 1-18.
Mayr, E. (1963) Animal Species and Evolution. Harvard University Press, Cambridge, MA.

McCartney, M.A., Acevedo, J., Heredia, C., Rico, C., Quenoville, B., Bermingham, E. \& McMillan, W.O. (2003) Genetic mosaic in a marine species flock. Mol. Ecol., 12, 2963-2973.

Miglietta, M.P., Faucci, A. \& Santini, F. (2011) Speciation in the sea: overview of the symposium and discussion of future directions. Integr. Comp. Biol., 51, 449-455.

Mokady, O. \& Brickner, I. (2001) Host-associated speciation in a coral-inhabiting barnacle. Mol. Biol. Evol., 18, 975-981.

Moore, W.S. (1995) Inferring phylogenies from mtDNA variation: mitochondrial-gene trees sersus nuclear-gene trees. Evolution, 49, 718-726.

Munday, P.L., Van Herwerden, L. \& Dudgeon, C.L. (2004) Evidence for sympatric speciation by host shift in the sea. Curr. Biol., 14, 1498-1504.

Munehara, H., Kanamoto, Z. \& Miura, T. (2000) Spawning behavior and interspecific breeding in three Japanese greenlings (Hexagrammidae). Ichthyol. Res., 47, 287-292.

Narum, S.R. \& Hess, J.E. (2011) Comparison of $F_{\text {ST }}$ outlier tests for SNP loci under selection. Mol. Ecol. Resour., 11, 184-194.

Neuenfeldt, S., Righton, D., Neat, F., Wright, P.J., Svëdang, H., Michalsen, K., Subbey, S., Steingrund, P., Thorsteinsson, V., Pampoulie, C., Andersen, K.H., Pedersen, M.W. \& Metcalfe, J. (2013) Analysing migrations of Atlantic cod Gadus morhua in the north-east Atlantic Ocean: then, now and the future. J. Fish Biol., 82, 741-763.

Nielsen, E.E., Grønkjær, P., Meldrup, D. \& Paulsen, H. (2005) Retention of juveniles within a hybrid zone between North Sea and Baltic Sea Atlantic cod (Gadus morhua). Can.J. Fish. Aquat. Sci., 62, 2219-2225.

Niemiller, M.L., Fitzpatrick, B.M. \& Miller, B.T. (2008) Recent divergence with gene flow in Tennessee cave salamanders (Plethodontidae: Gyrinophilus) inferred from gene genealogies. Mol. Ecol., 17, 2258-2275.

Niemiller, M.L., Nosil, P. \& Fitzpatrick, B.M. (2010) 
Norris, R.D. (2000) Pelagic species diversity, biogeography, and evolution. Paleobiology, 26, $236-258$.

Nosil, P. (2008) Speciation with gene flow could be common. Mol. Ecol., 17, 2103-2106.

Van Oppen, M.J.H., Bongaerts, P., Underwood, J.N., Peplow, L.M. \& Cooper, T.F. (2011) The role of deep reefs in shallow reef recovery: An assessment of vertical connectivity in a brooding coral from west and east Australia. Mol. Ecol., 20, 1647-1660.

Olivi, G. (1792) Zoologia Adriatica, ossia catalogo ragionato degli animali del golfo e della lagune di Venezia. Bassano. G. Remondini e fl., Bassano.

Ortiz-Barrientos, D., Grealy, A. \& Nosil, P. (2009) The genetics and ecology of reinforcement: implications for the evolution of prezygotic isolation in sympatry and beyond. Ann. N.Y. Acad. Sci., 1168, 156-182.

Ott, F.D. (1995) The taxa depicted in E.J.C. Esper's "Die Pflanzenthiere in Abbildungen nach der Natur" (1788-1830) and its "Fortsetzungen" (1794-1806) with a combined index to both works. Ann. Naturh. Mus. Wien, B, 97, 1-36.

Pallas, P.S. (1814) Zoographia Rosso-Asiatica, sistens omnium animalium in extenso Imperio Rossico et adjacentibus maribus observatorum recensionem, domicilia, mores et descriptiones anatomen atque icones plurimorum, 3 volumes. Academia Scientiarum, Petropolis.

Palumbi, S.R. (1992) Marine speciation on a small planet. Trends Ecol. Evol., 7, 114-118.

Panova, M., Hollander, J. \& Johannesson, K. (2006) Site-specific genetic divergence in parallel hybrid zones suggests nonallopatric evolution of reproductive barriers. Mol. Ecol., 15, 4021-4031.

Peijnenburg, K.T.C.A. \& Goetze, E. (2013) High evolutionary potential of marine zooplankton. Ecol. Evol., 3, 2765-2781.

Le Pennec, G., Butlin, R.K., Jonsson, P.R., Larsson, A.I., Lindborg, J., Bergström, E., Westram, A.M. \& Johannesson, K. (2017) Adaptation to dislodgement risk on wave-swept rocky shores in the snail Littorina saxatilis. PLoS One, 12, e0186901.
Perry, G. (1810-1811) Arcana, or Museum of Nature: containing Delineations of the most recent Discoveries, on the Subject of Natural History: classical and descriptive Explanation, 21 parts. Smeeton, London.

Peters, W.C.H. (1864) Über eine neue Percoidengattung, Plectroperca, aus Japan und eine neue Art von Haifischen, Crossorhinus tentaculatus, aus Neuholland. Monatsber. Akad. Berlin, 1864, 121-126.

Peters, W.C.H. (1869) Über neue oder weniger bekannte Fische des Berliner Zoologischen Museums. Monatsber. Akad. Berlin, 1869, 703-711.

Pettengil, J.B. \& Moeller, D.A. (2012) Phylogeography of speciation: allopatric divergence and secondary contact between outcrossing and selfing Clarkia. Mol. Ecol., 21, 4578-4592.

Pfennig, D.W. (2013). Inviable immigrants drive diversification in the sea. Proc. Natl. Acad. Sci. U.S.A., 110, 3713-3714.

Picq, S., McMillan, W.O. \& Puebla, O. (2016) Population genomics of local adaptation versus speciation in coral reef fishes (Hypoplectrus spp, Serranidae). Ecol. Evol., 6, 2109-2124.

Plaisance, L., Caley, M.J., Brainard, R.E. \& Knowlton, N. (2011) The diversity of coral reefs: what are we missing? PLoS One, 6, e25026.

Poey, F. (1851-1854) Memorias sobre la historia natural de la Isla de Cuba, acompañadas de sumarios Latinos y extractos en Francés, 1-463. Bercina, La Habana 1 [For dates of publication of parts see p. 449 and Norman 1938 [ref. 7314]; published Nov. 1851-June 1854.]

Poey, A. (1868) Synopsis piscium cubensium. Catalogo Razonado de los peces de la isla de Cuba. Repertorio Fisico-Natural de la Isla de Cuba, 2, 279-484.

Poortvliet, M., Olsen, J.L., Croll, D.A., Bernardi, G., Newton, K., Kollias, S., O’Sullivan, J., Fernando, D., Stevens, G., Galván Magaña, F., et al. (2015) A dated molecular phylogeny of manta and devil rays (Mobulidae) based on mitogenome and nuclear sequences. Mol. Phylogenet. Evol., 83, $72-85$. 
Potkamp, G., Vermeij, M.J.A. \& Hoeksema, B.W. (2017) Genetic and morphological variation in corallivorous snails (Coralliophila spp.) living on different host corals at Curaçao, southern Caribbean. Contrib. Zool., 86, 111-144.

Prada, C. \& Hellberg, M.E. (2013) Long prereproductive selection and divergence by depth in a Caribbean candelabrum coral. Proc. Natl. Acad. Sci. U.S.A., 110, 3961-3966.

Prada, C. \& Hellberg, M.E. (2014) Strong natural selection on juveniles maintains a narrow adult hybrid zone in a broadcast spawner. Am. Nat., 184, 702-713.

Prada, C., Schizas, N.V. \& Yoshioka, P.M. (2008). Phenotypic plasticity or speciation? A case from a clonal marine organism. BMC Evol. Biol, $8,1-19$.

Puebla, O., Bermingham, E. \& Guichard, F. (2008) Population genetic analyses of Hypoplectrus coral reef fishes provide evidence that local processes are operating during the early stages of marine adaptive radiations. Mol. Ecol., 17, $1405^{-1415}$.

Puebla, O., Bermingham, E. \& Guichard, F. (2012) Pairing dynamics and the origin of species. Proc. R. Soc. London, Ser. B, 279, 1085-1092.

Puebla, O., Bermingham, E., Guichard, F. \& Whiteman, E. (2007) Colour pattern as a single trait driving speciation in Hypoplectrus coral reef fishes? Proc. R. Soc. London, Ser. B, 274, 1265-1271.

Puebla, O., Bermingham, E. \& McMillan, W.O. (2014) Genomic atolls of differentiation in coral reef fishes (Hypoplectrus spp., Serranidae). Mol. Ecol., 23, 5291-5303.

Quesada, H., Posada, D., Caballero, A., Morán, P. \& Rolán-Alvarez, E. (2007) Phylogenetic evidence for multiple sympatric ecological diversification in a marine snail. Evolution, 61, 1600-1612.

Ramon, M.L., Lobel, P.S. \& Sorenson, M.D. (2003). Lack of mitochondrial genetic structure in hamlets (Hypoplectrus spp.): recent speciation or ongoing hybridization? Mol. Ecol., 12, $2975^{-2980 .}$

Rasmussen, A.R., Elmberg, J., Sanders, K.L. \& Gravlund, P. (2012) Rediscovery of the rare sea snake
Hydrophis parviceps Smith 1935: identification and conservation status. Copeia, 2012, 276-282.

Rathbun, M.J. (1901) Investigations of the Aquatic Resources and Fisheries of Porto Rico by the United States Fish Commission Steamer Fish Hawk in 1899. The Brachyura and Macrura of Porto Rico. Bull. U.S. Fish Comm., 20 [for 1900, preprint dated 1901, published in journal in 1902], 1-127.

Reaka-Kudla, M.L. (1997) The global biodiversity of coral reefs: a comparision with rain forests. In: Biodiversity II: Understanding and Protecting Our Biological Resources, M.L. Reaka-Kudla, D.E. Wilson \& E.O Wilson (Eds), pp. 83-108. Joseph Henry Press, Washington DC.

Reid, D.G., Dyal, P. \& Williams, S.T. (2012) A global molecular phylogeny of 147 periwinkle species (Gastropoda, Littorininae). Zool. Scr., 41, $125^{-136 .}$

Rice, W.R. (1984) Disruptive selection on habitat preference and the evolution of reproductive isolation: a simulation study. Evolution, 38, 1251-1260.

Rice, W.R. (1987) Speciation via habitat specialization: the evolution of reproductive isolation as a correlated character. Evol. Ecol., 1, 301-314.

Rice, W.R. \& Salt, G.W. (1988) Speciation via disruptive selection on habitat preference: experimental evidence. Am. Nat., 131, 911-917.

Ritson-Williams, R., Shjegstad, S. \& Paul, V. (2003) Host specificity of four corallivorous Phestilla nudibranchs (Gastropoda: Opisthobranchia). Mar. Ecol. Prog. Ser., 255, 207-218.

Ritson-Williams, R., Shjegstad, S.M. \& Paul, V.J. (2007) Larval metamorphic competence in four species of Phestilla (Gastropoda; Opisthobranchia).J. Exp. Mar. Biol. Ecol., 351, 160-167.

Ritson-Williams, R., Shjegstad, S.M. \& Paul, V.J. (2009) Larval metamorphosis of Phestilla spp. in response to waterborne cues from corals. J. Exp. Mar. Biol. Ecol., 375, 84-88.

Robert, C.P., Cornuet, J.-M., Marin, J.-M. \& Pillai, N.S. (2011) Lack of confidence in approximate Bayesian computation model choice. Proc. Nat. Acad. Sci., 108, 15112-15117. Downloaded from Brill.com04/26/2023 09:21:23AM via free access 
Rocha, L.A. \& Bowen, B.W. (2008) Speciation in coral-reef fishes. J. Fish Biol., 72, 1101-1121.

Rocha, L.A., Craig, M.T. \& Bowen, B.W. (2007) Phylogeography and the conservation of coral reef fishes. Coral Reefs, 26, 501-512.

Rocha, L.A., Lindeman, K.C., Rocha, C. \& Lessios, H.A. (2008). Historical biogeography and speciation in the reef fish genus Haemulon (Teleostei: Haemulidae). Mol. Phylogenet. Evol., 48, 918-928.

Rocha, L.A., Robertson, D.R., Roman, J. \& Bowen, B.W. (2005) Ecological speciation in tropical reef fishes. Proc. R. Soc. London, Ser. B, 272, 573-579.

Rolán-Alvarez, E. (2007) Sympatric speciation as a by-product of ecological adaptation in the Galician Littorina saxatilis hybrid zone.J. Molluscan Stud., 73, 1-10.

Rolán-Alvarez, E., Erlandsson, J., Johannesson, K. \& Cruz, R. (1999) Mechanisms of incomplete prezygotic reproductive isolation in an intertidal snail: testing behavioural models in wild populations. J. Evol. Biol., 12, 879-89o.

Rolán-Alvarez, E., Johannesson, K. \& Erlandsson, J. (1997). The maintenance of a cline in the marine snail Littorina saxatilis: the role of home site advantage and hybrid fitness. Evolution, 51, 1838-1847.

Rougemont, Q., Roux, C., Neuenschwander, S., Goudet, J., Launey, S. \& Evanno, G. (2016) Reconstructing the demographic history of divergence between European river and brook lampreys using approximate Bayesian computations. PeerJ, 4, e1910.

Rouse, G.W., Goffredi, S.K. \& Vrijenhoek, R.C. (2004) Osedax: bone-eating marine worms with dwarf males. Science (Washington DC), 305(5684), 668-671.

Rouse, G.W., Worsaae, K., Johnson, S.B., Jones, W.J. \& Vrijenhoek, R.C. (2008) Acquisition of dwarf male "harems" by recently settled females of Osedax roseus n. sp. (Siboglinidae; Annelida). Biol. Bull., 214(1), 67-82.

Roux, C., Fraïsse, C., Castric, V., Vekemans, X., Pogson, G.H. \& Bierne, N. (2014) Can we continue to neglect genomic variation in introgression rates when inferring the history of speciation? A case study in a Mytilus hybrid zone. J. Evol. Biol., 27, 1662-1675.

Roux, C., Tsagkogeorga, G., Bierne, N. \& Galtier, N. (2013) Crossing the species barrier: genomic hotspots of introgression between two highly divergent Ciona intestinalis species. Mol. Biol. Evol., 30, 1574-1587.

Rudman, W.B. (1981) Further studies on the anatomy and ecology of opisthobranch molluscs feeding on the scleractinian coral Porites. Zool. J. Linn. Soc., 71, 373-412.

Rundle, H.D. \& Nosil, P. (2005). Ecological speciation. Ecol. Lett., 8, 336-352.

Rützler, K., Duran, S. \& Piantoni, C. (2007) Adaptation of reef and mangrove sponges to stress: evidence for ecological speciation exemplified by Chondrilla caribensis new species (Demospongiae, Chondrosida). Mar. Ecol., 28, 95-111.

Sanders, K.L., Lee, M.S.Y., Mumpuni, Bertozzi, T. \& Rasmussen, A.R. (2013a) Multilocus phylogeny and recent rapid radiation of the viviparous sea snakes (Elapidae: Hydrophiinae). Mol. Phylogenet. Evol., 66, 575-591.

Sanders, K.L., Rasmussen, A.R., Mumpuni, Elmberg, J., De Silva, A., Guinea, M.L. \& Lee, M.S.Y. (2013b) Recent rapid speciation and ecomorph divergence in Indo-Australian sea snakes. Mol. Ecol., 22, 2742-2759.

Sang, T. \& Zhong, Y. (2000). Testing hybridization hypotheses based on incongruent gene trees. Syst. Biol., 49, 422-434.

Sarno, D., Kooistra, W., Medlin, L., Percopo, I. \& Zingone, A. (2005). Diversity in the genus Skeletonema (Bacillariophyceae). II. An assessment of the taxonomy of $S$. costatum-like species with the description of four new species. J. Phycol., 41, 151-176.

Schenck, G. (1939) Revised nomenclature for some nuculid pelecypods. J. Paleontol., 13(1), 21-41.

Schilthuizen, M. (2000) Dualism and conflicts in understanding speciation. BioEssays, 22, 1134-1141. 
Schilthuizen, M., van Til, A., Salverda, M., Liew, T.S., James, S.S., Bin Elahan, B. \& Vermeulenm J.J. (2006) Microgeographic evolution of snail shell shape and predator behavior. Evolution, 6o, 1851-1858.

Schluter, D. (1998) Ecological causes of speciation. In: Endless Forms: Species and Speciation, D.J. Howard \& S.H. Berlocher (Eds), pp. 114-129. Oxford University Press. Oxford.

Schluter, D. (2001) Ecology and the origin of species. Trends Ecol. Evol., 16, 372-38o.

Schluter, D. (2009) Evidence for ecological speciation and its alternative. Science, 323, 737-741.

Schwander, T., Libbrecht, R. \& Keller, L. (2014) Supergenes and complex phenotypes. Curr. Biol., 24, R288-R294.

Serrano, X.M., Baums, I.B., O’Reilly, K., Smith, T.B., Jones, R.J., Shearer, T.L., Nunes, F.L.D. \& Baker, A.C. (2014) Geographic differences in vertical connectivity in the Caribbean coral Montastraea cavernosa despite high levels of horizontal connectivity at shallow depths. Mol. Ecol., 23, 4226-4240.

Serrano, X.M., Baums, I.B., Smith, T.B., Jones, R.J., Shearer, T.L. \& Baker, A.C. (2016) Long distance dispersal and vertical gene flow in the Caribbean brooding coral Porites astreoides. Sci. Rep., 6,21619 .

Servedio, M.R., Van Doorn, G.S., Kopp, M., Frame, A.M. \& Nosil, P. (2011) Magic traits in speciation: 'magic' but not rare? Trends Ecol. Evol., 26, 389-397.

Shaw, J.K. \& Hopkins, T.S. (1977). The distribution of the family Hapalocarcinidae (Decapoda, Brachyura) on the Florida Middle Ground with a description of Pseudocryptochirus hypostegus new species. Proc. 3rd Intern. Coral Reef Symp., Miami, 1, 177-183.

Shibukawa, K., Suzuki, T. \& Aizawa, M. (2013) Gobiodon aoyagii, a new coral goby (Actinopterygii, Gobiidae, Gobiinae) from the West Pacific, with redescription of a similarly-colored congener Gobiodon erythrospilus Bleeker, 1875. Bull. Nat. Mus. Nat. Sci. A (Zoology), 39, 143-165.
Shine, R. (2005) All at sea: aquatic life modifies mate-recognition modalities in sea snakes (Emydocephalus annulatus, Hydrophiidae). Behav. Ecol. Sociobiol., 57, 591-598.

Simmonds, S.E. (2016) Genomic signatures of natural selection and geographic isolation in corallivorous snails. University of California, Los Angeles. PhD Thesis.

Simmonds, S.E., Chou, V., Cheng, S.H., Rachmawati, R., Calumpong, H.P., Mahardika, G.N. \& Barber, P.H. (2018) Evidence of host-associated divergence from coral-eating snails (genus Coralliophila) in the Coral Triangle. Coral Reefs, 37, 355-371.

Simon, J.-C., D’Alençon, E., Guy, E., Jacquin-Joly, E., Jaquiéry, J., Nouhaud, P., Peccoud, J., Sugio, A. \& Streiff, R. (2015) Genomics of adaptation to host-plants in herbivorous insects. Brief. Funct. Genomics, 14, 413-423.

Sjöqvist, C., Godhe, A., Jonsson, P.R., Sundqvist, L. \& Kremp, A. (2013) Local adaptation and oceanographic connectivity patterns explain genetic differentiation of a marine diatom across the North Sea-Baltic Sea salinity gradient. Mol. Ecol., 24, 2871-2885.

Smith, M.A. (1935) The Sea-Snakes (Hydrophiidae). Dana Report, 8, 1-6.

Sobel, J.M., Chen, G.F., Watt, L.R. \& Schemske, D.W. (2010) The biology of speciation. Evolution, 64, 295-315.

Sodeland, M., Jorde, P.E., Lien, S., Jentoft, S., Berg, P.R., Grove, H., Kent, M.P., Arnyasi, M., Olsen, E.M. \& Knutsen, H. (2016) "Islands of divergence" in the Atlantic cod genome represent polymorphic chromosomal rearrangements. Genome Biol. Evol., 8, 1012-1022.

Sonnini, C.S. \& Latreille, P.A. (1801) Histoire naturelle des reptiles. 4 vols. Déterville, Paris.

Soria-Carrasco, V., Gompert, Z., Comeault A.A., Farkas, T.E., Parchman, T.L., Johnston, J.S., Buerkle, C.A., Feder, J.L., Bast, J., Schwander, T., et al. (2014) Stick insect genomes reveal natural selection's role in parallel speciation. Science, 344, 738-742. 
Sousa, V.C., Beaumont, M.A., Fernandes, P., Coelho, M.M. \& Chikhi, L. (2012) Population divergence with or without admixture: selecting models using an ABC approach. Heredity, 108, 521-530.

Sousa, V.C., Fritz, M., Beaumont, M.A. \& Chikhi, L. (2009) Approximate Bayesian computation without summary statistics: the case of admixture. Genetics, 181, 1507-1519.

Sousa, V.C., Grelaud, A. \& Hey, J. (2011) On the nonidentifiability of migration time estimates in isolation with migration models. Mol. Ecol., 20, 3956-3962.

Stanhope, M.J., Hartwick, B. \& Baillie, D. (1993) Molecular phylogeographic evidence for multiple shifts in habitat preference in the diversification of an amphipod species. Mol. Ecol., 2, 99-112.

Stanhope, M.J., Leighton, B.J. \& Hartwick, B. (1992) Polygenic control of habitat preference and its possible role in sympatric population subdivision in an estuarine crustacean. Heredity, 69, 279-288.

Stella, J.S., Pratchett, M.S., Hutchings, P.A. \& Jones, G.P. (2011) Coral-associated invertebrates: diversity, ecological importance and vulnerability to disturbance. Oceanogr. Mar. Biol., 49, 43-104.

Stevens, P.M. (1990) A genetic analysis of the pea crabs (Decapoda: Pinnotheridae) of New Zealand. I. Patterns of spatial and host-associated genetic structuring in Pinnotheres novaezelandiae Filhol.J. Exp. Mar. Biol. Ecol., 141, 195-212.

Stewart, J.D., Beale, C.S., Fernando, D., Sianipar, A.B., Burton, R.S., Semmens, B.X. \& AburtoOropeza, O. (2016) Spatial ecology and conservation of Manta birostris in the Indo-Pacific. Biol. Conserv., 200, 178-183.

Stimpson, W. (1856) On some Californian Crustacea. Proc. Calif. Acad. Sci., 1, 87-90.

Strasburg, J.L. \& Rieseberg, L.H. (2011) Interpreting the estimated timing of migration events between hybridizing species. Mol. Ecol, 20, 2353-2366.

Strasburg, J.L. \& Rieseberg, L.H. (2013) Methodological challenges to realizing the potential of hybridization research. J. Evol. Biol., 26, 259-260.

Takahata, N. \& Slatkin, M. (1984) Mitochondrial gene flow. Proc. Natl. Acad. Sci. U.S.A., 81, 1764-1767.

Taylor, J.B. (1975) Planktonic prosobranch veligers of Kaneche Bay. PhD Thesis. University of Hawai'i.

Temminck, C.J. \& Schlegel, H. (1843) Pisces. In: P.F. Von Siebold (ed.), Fauna Japonica, sive descriptio animalium quae in itinere per Japoniam suscepto annis 1823-30 collegit, notis observationibus et adumbrationibus illustravit P.F. de Siebold, Part 1, pp. 1-20. Muller \& Co, Amsterdam.

Templeton, A.R. (2009) Statistical hypothesis testing in intraspecific phylogeography: nested clade phylogeographical analysis vs. approximate Bayesian computation. Mol. Ecol., 18, 319-331.

Templeton, A.R. (2010) Coherent and incoherent inference in phylogeography and human evolution. Proc. Natl. Acad. Sci. U.S.A., 107, 6376-6381.

Teske, P.R., Cherry, M.I. \& Matthee, C.A. (2004) The evolutionary history of seahorses (Syngnathidae: Hippocampus): molecular data suggest a West Pacific origin and two invasions of the Atlantic Ocean. Mol. Phylogenet. Evol., 30, 273-286.

Thomson, C.W. (1873) The Depths of the Sea. Macmillan and Co., London.

Van Tienderen, K.M. \& Van der Meij, S.E.T. (2017) Extreme mitochondrial variation in the Atlantic gall crab Opecarcinus hypostegus (Decapoda: Cryptochiridae) reveals adaptive genetic divergence over Agaricia coral hosts. Sci. Rep., 7, 39461.

Tsang, L.M., Chan, B.K.K., Shih, F.L., Chu, K.H. \& Allen Chen, C. (2009) Host-associated speciation in the coral barnacle Wanella milleporae (Cirripedia: Pyrgomatidae) inhabiting the Millepora coral. Mol. Ecol., 18, 1463-1475.

Turelli, M., Barton, N.H. \& Coyne, J.A. (2001). Theory and speciation. Trends Ecol. Evol., 16, 330-343. Ukuwela, K.D.B., Lee, M.S.Y., Rasmussen, A.R., de Silva, A., Mumpuni, Fry, B.G., Ghezellou, 
P., Rezaie-Atagholipour, M. \& Sanders, K.L. (2016) Evaluating the drivers of Indo-Pacific biodiversity: speciation and dispersal of sea snakes (Elapidae: Hydrophiinae). J. Biogeogr., $43,243-255$.

Ukuwela, K.D.B., Lee, M.S.Y., Rasmussen, A.R., De Silva, A. \& Sanders, K.L. (2017) Biogeographic origins of the viviparous sea snake assemblage (Elapidae) of the Indian Ocean. Ceylon J. Sci., 46, 101-110.

Via, S. (2001) Sympatric speciation in animals: the ugly duckling grows up. Trends Ecol. Evol., 16, 381-390.

Victor, B.C. \& Randall, J.E. (2010) Gramma dejongi, a new basslet (Perciformes: Grammatidae) from Cuba, a sympatric sibling species of $G$. loreto. Zool. Stud., 49, 865-871.

De Vienne, D.M., Refrégier, G., López-Villavicencio, M., Tellier, A., Hood, M.E. \& Giraud, T. (2013) Cospeciation vs host-shift speciation: methods for testing, evidence from natural associations and relation to coevolution. New Phytol., 198, $347-385$.

Vincent, A.C.J. \& Sadler, L.M. (1995) Faithful pair bonds in wild seahorses, Hippocampus whitei. Anim. Behav., 50, 1557-1569.

Vrijenhoek, R.C., Johnson, S.B. \& Rouse, G.W. (2009) A remarkable diversity of bone-eating worms (Osedax; Siboglinidae; Annelida). BMC Biol., 7, 74 .

Wagner, M. (1868) Die Darwin'sche Theorie und das Migrationsgesetz der Organismen. Dunker \& Humblot, Leipzig.

Walbaum, J.J. (1792) Petri Artedi sueci genera piscium. In quibus systema totum ichthyologiae proponitur cum classibus, ordinibus, generum characteribus, specierum differentiis, observationibus plurimis. Redactis speciebus 242 ad genera 52. Ichthyologiae pars III. Ant. Ferdin. Rose, Grypeswaldiae [Greifswald]. Part 3: i-viii + 1-723.

Walter, R.P., Kessel, S.T., Alhasan, N., Fisk, A.T., Heath, D.D., Chekchak, T., Klaus, R., Younis, M., Hill, G., Jones, B., et al. (2014) First record of living Manta alfredi $\times$ Manta birostris hybrid. Mar. Biodivers., 44, 1-2.
Warner, P.A., Van Oppen, M.J.H. \& Willis, B.L. (2015). Unexpected cryptic species diversity in the widespread coral Seriatopora hystrix masks spatial-genetic patterns of connectivity. Mol. Ecol., 24, 2993-3008.

Watson, R.B. (1879-1883) Mollusca of H.M.S. 'Challenger' Expedition. J. Linn. Soc. London, 14, 506529, 586-6o5, 692-716 [1879]; 15: 87-126, 217230 [1880], 245-274, 388-412, 413-455, 457-475 [1881]; 16: 247-254, 324-343, 358-372, 373-392, 494-611 [1882]; 17: 26-40, 112-130, 284-293, 319340, 341-346 [1883].

Weiner, A., Aurahs, R., Kurasawa, A., Kitazato, H. \& Kucera, M. (2012) Vertical niche partitioning between cryptic sibling species of a cosmopolitan marine planktonic protist. Mol. Ecol., 21, 4063-4073.

Wellenreuther, M., Barrett, P.T. \& Clements, K.D. (2007) Ecological diversification in habitat use by subtidal triplefin fishes (Tripterygiidae). Mar. Ecol. Prog. Ser., 330, 235-246.

Wellenreuther, M., Syms, C. \& Clements, K.D. (2008) Body size and ecological diversification in a sister species pair of triplefin fishes. Evol. Ecol., 22, 575-592.

Westram, A.M., Panova, M., Galindo, J. \& Butlin, R.K. (2016) Targeted resequencing reveals geographical patterns of differentiation for loci implicated in parallel evolution. Mol. Ecol., 25, 3169-3186.

White, W.T., Corrigan, S., Yang, L., Henderson, A.C., Bazinet, A.L., Swofford, D.L., Naylor, G.J.P. (2017) Phylogeny of the manta and devilrays (Chondrichthyes: Mobulidae), with an updated taxonomic arrangement for the family. Zool. J. Linn. Soc., 82, 6573 .

Whitley, G.P. (1931) New names for Australian fishes. Aust. Zool., 6, 310-334.

Won, Y.J. \& Hey, J. (2005) Divergence population genetics of chimpanzees. Mol. Biol. Evol., 22, 297-307.

Zann, L.P. (1987) A review of macrosymbiosis in the coral reef ecosystem. Int. J. Parasitol., 17, 399-405. 
Zardi, G.I., Nicastro, K.R., Canovas, F., Ferreira Costa, J., Serrão, E.A. \& Pearson, G.A. (2011) Adaptive traits are maintained on steep selective gradients despite gene flow and hybridization in the intertidal zone. PLoS One, 6, e19402.

Zardus, J.D., Etter, R.J., Chase, M.R., M.A. Rex \& Boyle, E.E. (2006) Bathymetric and geographic population structure in the pan-Atlantic deepsea bivalve Deminucula atacellana (Schenck, 1939). Mol. Ecol., 15, 639-651.

RECEIVED: 14 AUGUST 2018 | REVISED AND

ACCE PTED: 1 APRIL 2019

EDITOR: J.W. ARNTZEN 